\title{
Our Barns: Our Stories
}

by

Darby Ace

A thesis submitted to the Faculty of Graduate and Postdoctoral Affairs in partial fulfillment of the requirements for the degree of

Master of Architecture

M.Arch (Professional)

Carleton University

Ottawa, Ontario

(C) 2018

Darby Ace 


\begin{abstract}
This thesis will explore how the concept of intangible cultural heritage can inform the design of a tangible form in a changing cultural context. Specifically, it will question how the intangible concepts of community, craft, and story can inform a design strategy which acts to integrate the adaptive reuse of a traditional barn with its new suburban environment. The design strategy will prioritize flexibility both spatially and within the connection between old and new. Heritage buildings can act to inspire architects to think outside of the box and to raise the bar on suburban design.

Timber framed barns are beautifully exposed examples of traditional craft and serve as a reminder of the agricultural history of an area. Historic barns provide a unique opportunity to give a new sense of identity to the evolving suburban culture. This project will explore the technical, conceptual, and contextual implications of adaptive reuse of a barn in a suburban environment. The Bradley-Craig Farm at 590 Hazeldean Road, Stittsville, Ontario will serve as a case study for this research and adaptation.
\end{abstract}




\section{Acknowledgements}

I owe great thanks to everyone who has continuously supported me and encouraged me throughout this project. Sincere gratitude goes out to my thesis advisor Sheryl Boyle for her support and expertise throughout this entire process. Her leadership and passion has inspired me not only over the past eight months, but over the past six years.

I also must thank the community of Stittsville for their continued dedication to saving the piece of their heritage that is the Bradley-Craig barn; their commitment and sincerity continues to remind me of the purpose of this research and the importance of my work. Specifically, I would like to thank Marguerite Evans, Ottawa resident and descendant of the Bradley family for her enthusiasm towards my project and willingness to share her personal history and honest perspective. Appreciation is also extended to Richcraft Homes, the current owner of the Bradley-Craig property, for their cooperation in providing me with access to the site.

I am deeply thankful for my family and friends, who have pushed me to dig deeper and to never give up, and for my partner, Nick Richardson, who has supported me through the countless successes and frustrations along the way. The process of master's thesis has proven to be a highly personal and emotional task, one that although may be largely independent would not be possible without endless amounts of outside support, and to everyone who has been there for me in one way or another, I express my most sincere gratitude. 


\section{Table of Contents}

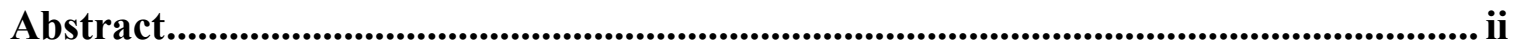

Acknowledgements ..........................................................................................................ii

Table of Contents ........................................................................................................ iv

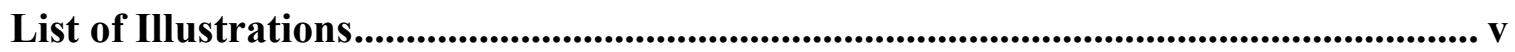

1 Chapter: Ontario's Evolving [agri]CULTURAL Landscape................................... 7

1.1 Community: [agri]CULTURE - Not Just Any Cultural Landscape ............................. 7

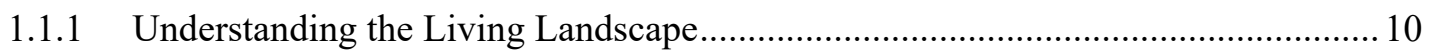

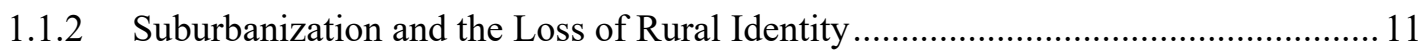

1.2 Story: The Value of Memories + The Beauty of Time............................................ 13

1.3 Craft: "Big Sticks” Timber Construction ............................................................. 15

2 Chapter: Case Study - Bradley-Craig Barn ............................................................... 18

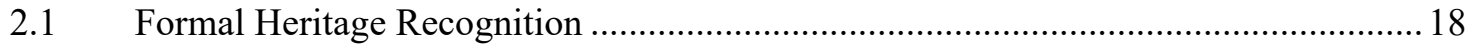

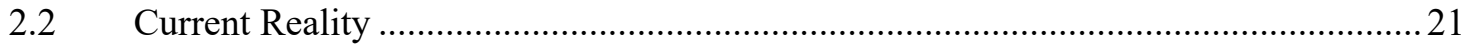

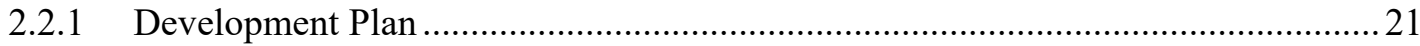

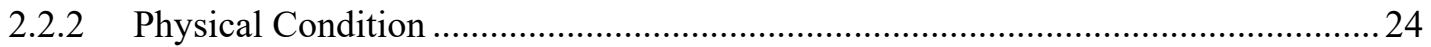

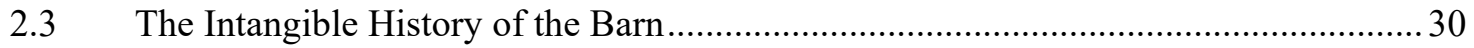

2.3.1 Story: The Evolution of the Barn and Cultural Landscape ..................................... 30

2.3.2 Craft: Physical Construction + Tangible Beauty.................................................. 34

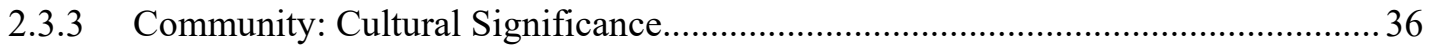

3 Chapter: ICH - a Strategy for Design .............................................................. 38

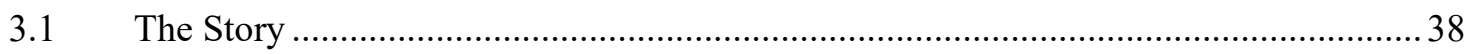

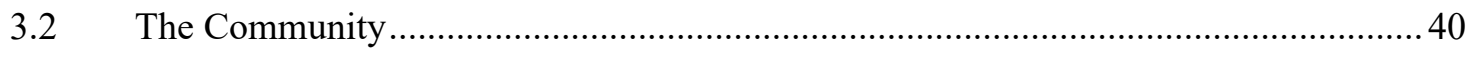

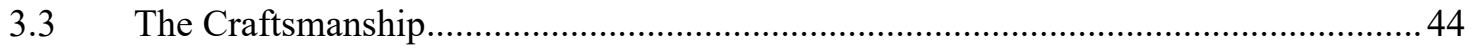

Bibliography or References..................................................................................................... 51 


\section{List of Illustrations}

Illustration 1 Conceptual photograph capturing Ontario's [agri]cultural landscape.... 9

Illustration 2 The aged patina of painted barn wood................................................. 15

Illustration 3 Stacked axonometric drawing: locating character defining elements... 20

Illustration 4 Surrounding land use under the Fernbank Community Design Plan.... 23

Illustration 5 Lower level plan, produced from laser scan data. ................................ 25

Illustration 6 Main level plan, produced from laser scan data - .............................. 26

Illustration 7 North elevation, produced from photogrammetric data........................ 27

Illustration $8 \quad$ East elevation, produced from photogrammetric data......................... 27

Illustration 9 South elevation, produced from photogrammetric data........................ 28

Illustration 10 West elevation, produced from photogrammetric data......................... 28

Illustration 11 Section 1A - east-west section, produced from laser scan data. .......... 29

Illustration 12 Section 2A - north-south section, produced from laser scan data........ 29

Illustration 13 Early 1890s photography of Bradley-Craig barn, south elevation. ...... 31

Illustration 14 The evolving landscape of Hazeldean Road $(1879-2017)$................. 33

Illustration 15 Mid-span timber connection, as found in the Bradley-Craig Barn....... 35

Illustration 16 Exterior timber connection, as found in Bradley-Craig Barn............... 35

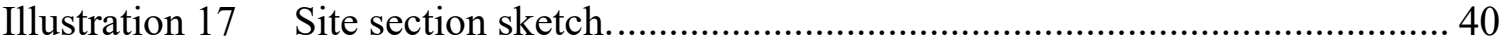

Illustration 18 Site plan - showing location of barn in broader development context. 42

Illustration 19 Main level plan, showing new schematic design and adjacent context.43

Illustration 20 Stacked axonometric diagram including massing of intervention........ 45

Illustration 21 Massing diagram of schematic design intervention.............................. 46 
Illustration 22 North elevation, showing new schematic design............................. 47

Illustration 23 East elevation, showing new schematic design. .................................. 47

Illustration 24 South elevation, showing new schematic design.............................. 48

Illustration 25 West elevation, showing new schematic design............................. 48

Illustration 26 Inset Glazing, Seamless Glazing, and Insulated Wall Details............. 49 


\section{Chapter: Ontario's Evolving [agri]CULTURAL Landscape}

Within the physical material of an old building lies the memories of cultural tradition and historical evolution. The cultural value lies in the story, the way in which a building has impacted the people around it and the way that people have impacted it. For the purpose of this study, formal heritage designations are insignificant, but the intangible values which a community associates with a structure are what must be protected. Each structure has a history, a character, and relationships with people along the way - a concept known as intangible cultural heritage (ICH). To summarize this concept as defined by UNESCO, intangible cultural heritage is, the practices, knowledge, skills, instruments, and cultural spaces which groups or sometimes individuals associate with their cultural past ${ }^{1}$. ICH is constantly redefined over time and provides the community or group with a sense of identity and continuity ${ }^{2}$.

A key component of Ontario's cultural heritage is the history of agricultural development, which is evident today through the numerous abandoned agricultural structures dispersed across the landscape. Specifically, I would like to focus on abandoned timber framed barns whose future is most often threatened by the sprawl of suburban development. Through the lens of intangible cultural heritage, I will assess the community, story, and craftsmanship, as applicable to historic timber framed barns.

\subsection{Community: [agri]CULTURE - Not Just Any Cultural Landscape}

Within the study of heritage conservation, cultural heritage is commonly used to describe all of which we understand as heritage today. The Council of Europe Framework Convention on the Value of Cultural Heritage for Society, better known as

\footnotetext{
1 "Intangible Cultural Heritage," UNESCO, accessed January 06, 2018. https://ich.unesco.org/en/what-isintangible-heritage-00003.

2 "Intangible Cultural Heritage," UNESCO, accessed January 06, 2018. https://ich.unesco.org/en/what-isintangible-heritage-00003.
} 
the Faro convention, focusses on the role heritage plays in cultural life and human rights. As defined in this document,

"Cultural heritage is a group of resources inherited from the past which people identify, independent of ownership, as a reflection and expression of their constantly evolving values, beliefs, knowledge and traditions. It includes all aspects of the environment resulting from the interaction between people and places through time", 3

Building upon the idea of cultural heritage, I would like to focus on the understanding of this concept as manifested in a broader setting, namely a cultural heritage landscape.

Within the City of Ottawa, a framework for growth and development of the city is set out within The City of Ottawa Official Plan. Within this document, cultural heritage landscape is defined as, "any geographic area that has been modified, influenced, or given special cultural meaning by people and that provides the contextual and spatial information necessary to preserve and interpret the understanding of important historical settings and changes to past patterns of land use" ${ }^{4}$. Furthermore, "Cultural landscapes are often dynamic, living entities that continually change because of natural and humaninfluenced social, economic and cultural processes" 5 . The dynamic nature of a cultural landscape is critical; I wish to highlight the importance of understanding the life of a place, not just as a singular snapshot but as an evolving story.

Over the past century, rural communities - specifically those within proximity to urban centres - have seen many changes due to technological advancements and evolving cultural values. I will explore the ways in which the barn structure can once again bring people together and reinforce a sense of identity in a newly suburban community.

Through education and reintegration of barns into the day-to-day culture of a community, the goal is to re-establish respect and cultural value for these beautiful structures, which in turn will ensure protection of such barns for generations to come. Barns are a product

\footnotetext{
3 "Faro Convention Action Plan," Council of Europe Portal, Culture and Cultural Heritage. Accessed February 28, 2018. https://www.coe.int/en/web/culture-and-heritage/faro-action-plan.

4 “Official Plan,” City of Ottawa, May 2003. https://ottawa.ca/en/city-hall/planning-and-development/ official-plan-and-master-plans/official-plan

5 “Official Plan,” City of Ottawa, May 2003. https://ottawa.ca/en/city-hall/planning-and-development/ official-plan-and-master-plans/official-plan
} 
of a specific culture, what I am calling [agri]culture. More specifically, the rural culture which developed from European settlement of Ontario in the early nineteenth century.
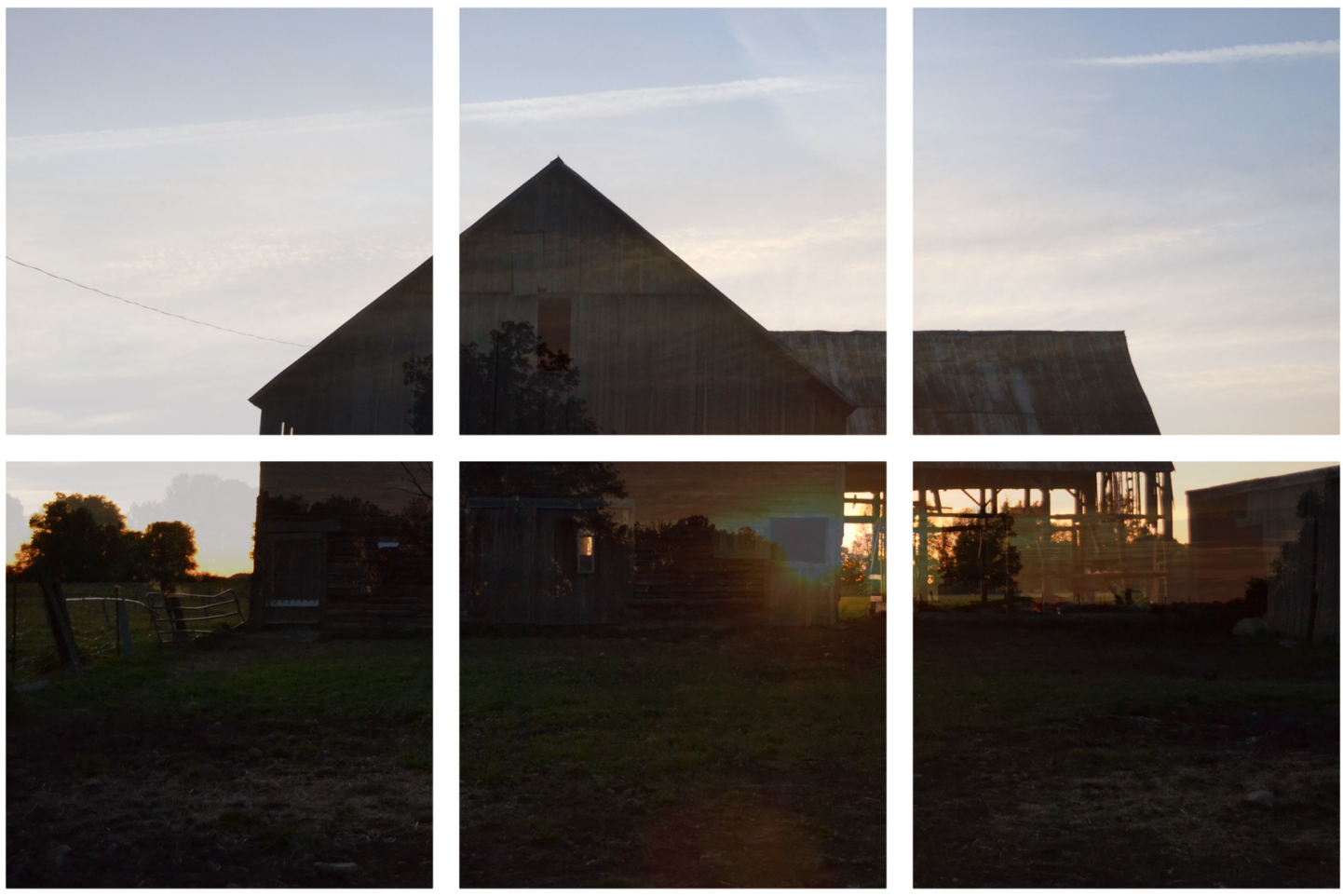

Illustration 1 Conceptual photograph capturing Ontario's [agri]cultural landscape. 


\subsubsection{Understanding the Living Landscape}

The writing of Thomas F. McIlwraith, geographer and professor from the University of Toronto, has greatly influenced my understanding of the evolution of rural Ontario. Looking for Old Ontario by McIlwraith, explores the history and evolution of the province and its cultural landscape, as well as provides insight into reading the story of a place through its built features. He explores what it means to read a landscape and the concept of a living landscape - ever growing and constantly reinvented through inhabitation ${ }^{6}$. In reference to the rural cultural landscape, McIlwraith quotes Ralph Waldo Emerson:

"the charming landscape which I saw this morning is indubitably made up of some twenty or thirty farms ... But none of them owns the landscape. There is a property in the horizon which no man has but he whose eyes can integrate all the parts, that is, the poet. This is the best part of these men's farms, yet to this their warranty-deeds give no title ${ }^{7}$."

The key to understanding the agri[cultural] landscape is accepting the value of context, community, and connections. A cultural landscape is about so much more than individual properties and can only be fully understood when seen as a whole. McIlwraith asserts, "the challenge is to become Emerson's poet, able to read Ontario convincingly despite having only incidental opportunity to disappear into its most private spaces" ${ }^{8}$. I believe this is both the challenge and the beauty. Intrigue of the unknown allows each individual to make a place their own, to read and imagine their own story.

McIlwraith discusses the concept of the living landscape, which he defines as a place "inhabited and continually reinvented" 9 . This concept is critical to this thesis and my understanding of agri[culture]. The cultural landscape as I will describe throughout this chapter, should be understood as layers of life, constantly growing, and adapting over time; however, critical to this understanding is accepting that each layer is an addition

\footnotetext{
${ }^{6}$ Thomas F. McIlwraith, Looking for Old Ontario (Toronto: University of Toronto Press Ltd, 1997), 6.

${ }^{7}$ McIlwraith, Looking for Old Ontario, 30.

${ }^{8}$ McIlwraith, Looking for Old Ontario, 31.

${ }^{9}$ McIlwraith, Looking for Old Ontario, 6.
} 
rather than an erasure, never covering up what came before but simply adding to, or building upon.

\subsubsection{Suburbanization and the Loss of Rural Identity}

Industrialization brought with it a movement from rural to urban settlement; however, the introduction of the automobile opened a new prospect of living, reintroducing people back into the countryside and beginning the consumption of agricultural land for suburban development. McIlwraith refers to suburbia as "the car's most profound legacy" and compares the severity of such effect on the landscape of Ontario to the devastation caused by deforestation in the $19^{\text {th }}$ century ${ }^{10}$. The effects of cars go beyond what one would initially recognize. Greater accessibility meant sprawl of housing over a greater area, and speed of travel meant a disconnect from one's surroundings.

On a broader scale, cars and other technological advancements have contributed to the rapid decline of family farms across much of North America. One of the primary causes, is the increased agricultural land value for commercial and domestic development. Historically, proximity to major urban centres made milk and produce profitable for farmers; today, that same accessibility has led to the crisis of suburban sprawl, covering the once distinguished countryside with a blanket of sameness.

Furthermore, changes in the farming industry have created a situation where small scale farms are no longer economically viable; mass production and efficiency overtook quality and craft with regards to rural wooden barns. On the topic of contemporary farming operations, authors of Barn: Preservation and Adaptation wrote, “The very intricacy of timber frames, which lend the old barns their intrinsic character, are now impediments to efficiency" ${ }^{11}$. This loss of surrounding farm land and decrease in

\footnotetext{
${ }^{10}$ McIlwraith, Looking for Old Ontario, 47.

${ }^{11}$ Elric Endersby, et al., Barn: Preservation \& Adaptation (New York: Rizzoli, 2014), 8-9.
} 
practicality is precisely why alternative and creative solutions for these striking structures must be considered.

\section{It Takes a Village to Raise a Barn}

Many historic barns utilized a method of assembly know as barn raising unique to $18^{\text {th }}$ and $19^{\text {th }}$ century North America, of which few examples remain. A barn raising bee is described as "a collective action of the community, in which a barn for one of the members is built (or rebuilt) by volunteer members of the community" ${ }^{12}$. In The Barn, the authors romanticize the idea of the barn raising bee, stating, "Nowhere is democracy and brotherhood of man better demonstrated than by the barn raising bee" ${ }^{13}$. The name of an architect does not define the barn, it is the story of a community and a master carpenter. There is a true beauty in this anonymous design and construction, the coming together to build a community, one timber at a time; however, Catherine Anne Wilson, a professor of rural history at the University of Guelph, proposes a different perspective on the "reciprocal bee", seeing beyond the optimistic idea that this collective action was all about community, kindness, and generosity. Wilson believes that,
"By examining how the bee actually functioned in an economic and social sense in the nineteenth century, we can better understand how the rural neighbourhood emerged, how informal labour markets were part of the social whole, and how the bee fit into the broader culture of Ontario." 14

Barn raising bees, and collective work bees as a whole, played an important role in the social culture of rural communities, as well, bees were a critical part of a "hidden economy" which allowed farming families to complete tasks and meet demands which were not possible with their individual means. As such, reciprocal work bees created interdependence within communities, allowing communities as a whole to become self-

\footnotetext{
${ }^{12}$ Commonwealth Resource Management. “A Cultural Heritage Impact Statement: Bradley/Craig Barn Demolition \& Relocation 590 Hazeldean Road, Ottawa” September, 2015, 18.

${ }^{13}$ Eric Arthur and Dudley Witney, The Barn: A Vanishing Landmark in North America (Toronto: M. F. Feheley Arts, 1972), 12.

${ }^{14}$ Catherine Anne Wilson, "Reciprocal Work Bees and the Meaning of Neighbourhood". Canadian Historical Review 82, no. 3 (September 2001): 2.
} 
sufficient opposed to individuals ${ }^{15}$. However, participation in work bees was not a selfless act but rather understood as integral to survival and prosperity. Manual labour became a commodity.

\subsection{Story: The Value of Memories + The Beauty of Time}

Architecture forms the backdrop for events in all areas of historical development. Beauty in architecture can come from the dialogue between past generations and our current interpretations of their built legacies. Intangible heritage lies deeper than the surface of the building materials; it lies within the spaces of walls, in the people who have passed through the doors, and in the role which a building played in the development of a community. It is our responsibility to not abandon or destroy the built fabric of the past but to reinterpret it for modern use. Within each of these reinterpreted forms there will exist a beauty and the presence of time that cannot be achieved through new construction: it is an ongoing story.

Appreciation for the story behind our built environment can be correlated to Sloane's interpretation of an antiquarian's desire for the "old". Sloane explains, "An antiquarian might argue that his interest in antiques is an appreciation of historic atmosphere, a love of the beauty of pleasing decay. More often, however, his interest in antique art boils down to a reverence for the individuality of the past, what man once stood for, the way he lived and the thoughts he thought" 16 . This search for the individuality of the past, a physical connection to a different time, can be achieved on a community scale through architecture, perhaps through barns; architecture holds the

\footnotetext{
${ }^{15}$ Catherine Anne Wilson, "Reciprocal Work Bees and the Meaning of Neighbourhood". Canadian Historical Review 82, no. 3 (September 2001): 5.

${ }^{16}$ Eric Sloane, A Reverence for Wood. Important Books, 2013, 26.
} 
potential to pass our story on for generations to come. In an excerpt from a personal letter, quoted by authors of The Barn, Marian Engel writes:

But the sheds fell down to the democrats and cutters; no stone-boats drew the milk-cans to the road; the families ran to girls and city-fellers; the hired men went away; and we were left with the stories ${ }^{17}$.

I hope to bring light to the value of preserving memories of the rural foundation upon which this province was built. The barn holds memories of the past, currently being overwritten by suburbanization; however, conversion of these structures is a means through which these stories may be passed on for years to come. However, the intent of this project is not to grasp at a nostalgia for a past way of life. In contrast, the goal of the project is to view this community as a continuously evolving story and to encourage each generation to continue to add their layer to the story, to adapt the barn to changing needs.

\section{The Beauty of Time}

Each built form tells its own unique story through the visible evidence of time. Our built landscape becomes a record of who we are, what we have done or accomplished, and how we have changed. This idea builds upon a beautiful metaphor, proposed by McIlwraith, for the evolving cultural landscape:

'Palimpsest' [he says] means 'rubbed again'. It is a label applied to ancient parchments that have been written on again and again but imperfectly erased between successive uses. What a fine way to describe southern Ontario 's landscape, including its buildings, repeatedly altered but always showing what went before ${ }^{18}$.

The author's idea of "palimpsest" - a layering of buildings, landscape, and culture over time - is tied to an understanding of landscape, dating back to the $1960 \mathrm{~s}$, which prioritizes the idea of the land as "a palimpsest, the people's own manuscript, their handmade history book" ${ }^{19}$. The idea of celebrating and accepting layers of life into our

\footnotetext{
${ }^{17}$ Eric Arthur and Dudley Witney, The Barn: A Vanishing Landmark in North America (Toronto: M. F. Feheley Arts, 1972), 26.

18 Thomas F. McIlwraith, Looking for Old Ontario (Toronto: University of Toronto Press Ltd, 1997), 31.

${ }^{19}$ McIlwraith, Looking for Old Ontario, 16.
} 
appreciation of heritage is one that I wish to highlight in my project, both through my analysis of the evolution of site and building and through my approach to incorporating the barn into the community for generations to come.

Over time, sun and weather transform the patina of untreated wood to a grey tone. This aesthetic is trendy in contemporary design; however, the grey patina of aged wood represents so much more than a pleasing aesthetic. This evidence of time alludes to the story of the building, years of storms, changes of seasons, and days of sunshine. Perhaps the appeal of naturally aged wood on the human mind goes deeper than a trend. Perhaps the intrigue of time and story play a role in the psychological attraction to the material.

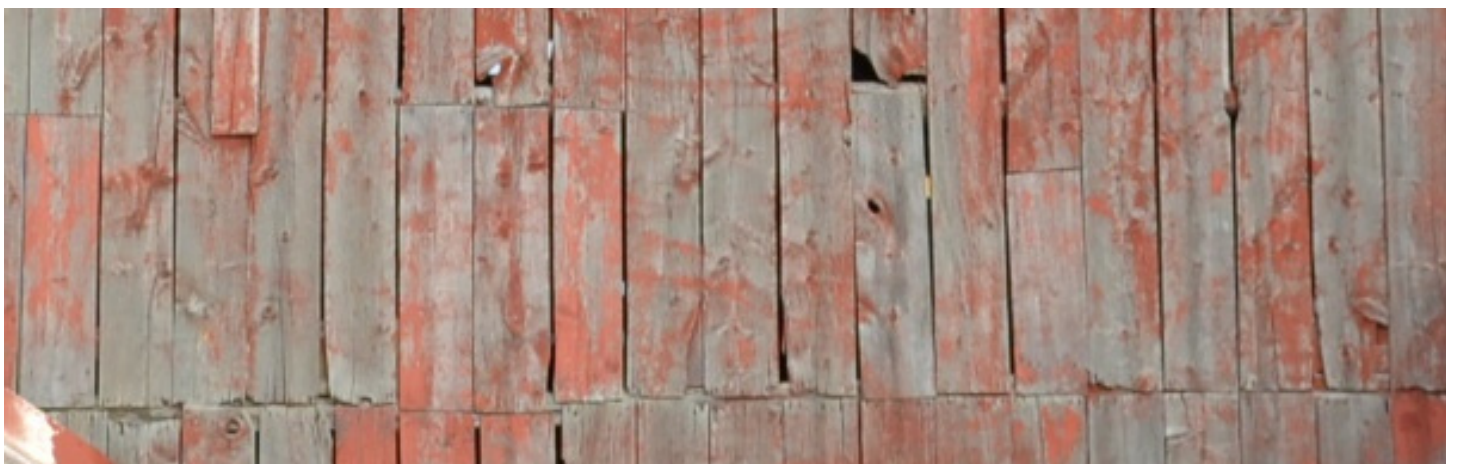

\section{Illustration 2 The aged patina of painted barn wood.}

\subsection{Craft: "Big Sticks" Timber Construction}

Traditional timber construction is a dying art, a craft of detail, time, and human touch. As no two barns are the same, each lost barn means a loss in understanding of craft and construction, not to mention the intangible cost of cultural memories. "In just the last decade thousands of barns have been lost. We, and the legacy we have been entrusted to maintain, are much poorer for the rapid recession of the rural landscape they once dominated" ${ }^{20}$. Upon settlement, wood was the preferred construction material for many reasons, accessibility, and forgivingness of the material, as well as, ease of construction

\footnotetext{
${ }^{20}$ Elric Endersby, et al., Barn: Preservation \& Adaptation (New York: Rizzoli, 2014), 11.
} 
21. "It is to the barns of the last two hundred years that we go to see an unspoilt indigenous architecture where everything was wrought by human hands" ${ }^{22}$. Through knowledge of historical construction, including craft, material, and process, we might gain a greater appreciation for this cultural resource which is too often undervalued.

In many cases, the physical components of a building are the first things people consider when thinking of heritage architecture; however, many of the tangible aspects of the building, such as the physical materials, take on intangible value over time. The uniqueness and scarcity of the physical material and the loss of traditional craft is often overlooked. Timber framed barns are beautifully exposed examples of traditional craft, often including hand hewn timbers, mortise and tenon joinery, and careful selection of old growth lumber that is nearly impossible to access today. Conservation of these structures holds the potential to also preserve knowledge of traditional construction, skills, and materials, and the possibility to use architecture as a teaching tool to pass this knowledge on for generations to come. To understand the potential for adaptation of timber framed barns, one must first appreciate the construction: material, craft, and process. Knowledge of the way a building was made allows one to comprehend the way a building functions, the forces acting on it, the way it moves, its strengths, and its weaknesses. The function, design, and construction of a timber framed barn are all directly connected and relatively unchanged from original conception to present day.

Traditional construction took advantage of natural material qualities to optimize their design. For example, the wooden pegs, or trunnels - treenails - provided a secure connection between members and allowed for movement within the joints with moisture and temperature changes ${ }^{23}$. Furthermore, gaps were purposely left between exterior barn board cladding to allow for air circulation. As labour costs increased, attention to detail and quality of hand craft in vernacular structures became a thing of the past. An excerpt

${ }^{21}$ Thomas F. McIlwraith, Looking for Old Ontario (Toronto: University of Toronto Press Ltd, 1997), 71.

${ }^{22}$ Eric Arthur and Dudley Witney, The Barn: A Vanishing Landmark in North America (Toronto: M. F. Feheley Arts, 1972), 12.

23 Eric Sloane, A Reverence for Wood. Important Books, 2013, 37. 
from a poem My Barn by Dean Hughes, illustrates the pride a farmer took in his wellcrafted barn,

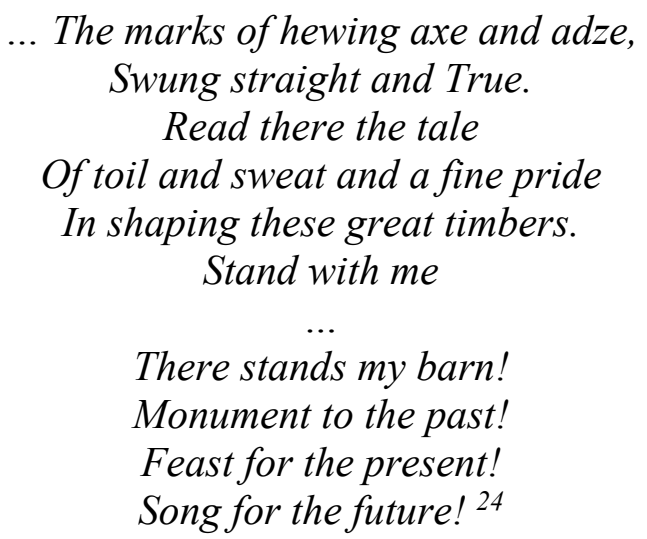

Changes in technology and quality of building materials over time has directly impacted the visual and structural qualities of our buildings; as such, the cultural value of wellcrafted timber barns should only increase. Unfortunately, appreciation of aspects such as material and craft has decreased as society places greater value on quantity and speed. Industrialization brought a movement toward ease and efficiency and away from handcraft. The importance of time, craft, and detail is a lesson that should be taken from these beautiful structures.

${ }^{24}$ Eric Arthur and Dudley Witney, The Barn: A Vanishing Landmark in North America (Toronto: M. F. Feheley Arts, 1972), 24. 


\section{Chapter: Case Study - Bradley-Craig Barn}

The Bradley-Craig Farm at 590 Hazeldean Road, Stittsville, will serve as a case study for my research. The history of this farm dates back as far as 1824 and remained in the same family until 2006 when it was sold to a developer. The intangible cultural heritage of this farm is extensive and strong, from first settlement, to agricultural development, and local crafts-persons. As suburban commercial and domestic development consumes the area, this remarkable structure, and the stories it holds, are at risk of being lost forever. Preservation of the farm will not only serve as a reminder of the rural heritage of the town of Stittsville but will also preserve the diminishing art of traditional timber craft.

\subsection{Formal Heritage Recognition}

The Ontario Heritage Act was initiated in 1975, in response to a growing concern for the preservation of historic buildings and neighbourhoods across the province; the legislation enabled municipalities to protect properties of architectural and historical significance $^{25}$. This act was also one of the first means through which vernacular buildings, buildings without typical cultural or architectural values, could be celebrated and protected. This protection is particularly necessary in areas such as Stittsville, where urban and suburban development is prioritized over the protection of rural land and culture.

In 2010, a four-acre portion of the 120-acre Bradley-Craig farm was granted formal designation under Part IV of the Ontario Heritage Act. This heritage property is formally known as 590 Hazeldean Road, reference number ACS2010-ICS-PGM-0021. According to Heritage Ottawa, this designation was integral to the rezoning of the adjacent farm land for development. This farm is historically significant for reasons

\footnotetext{
25 “Ontario Heritage Act," City of Ottawa, last modified February 28, 2017,
} http://www.mtc.gov.on.ca/en/heritage/heritage_act.shtml 
which include "its identity as a vestige to the pioneer farm, the historical relevance of its occupants, the physical structures themselves and the evolution of a way of life" 26 . Designation was not granted lightly. Ontario regulation 9/06 determines a property to have contextual value if a property meets one out of three criteria; however, the Bradley Craig Farm meets all three: design value or physical value, historical value or associative value, and contextual value. These values more than justify protection and integration of this barn as an integral part of the developing community.

The character of the barn is defined by its unique architecture, traditional construction, and quality craftsmanship. As such, features like the monitor roofline, the stone foundations, the timber frame construction, the purlin frame knee wall, the mortise and tenon joinery, the wood cladding, the diamond-shaped clerestory windows, and the raised, two-bay barn plan all contribute to the heritage value of the building. The Bradley-Craig Farmstead, as seen today, is a fraction of what once was a successful and influential working farm; however, what remains is an important reminder of the rural history of the land and community.

\footnotetext{
${ }^{26}$ Commonwealth Resource Management. "A Cultural Heritage Impact Statement: Bradley/Craig Barn Demolition \& Relocation 590 Hazeldean Road, Ottawa” September 2015, 15.
} 


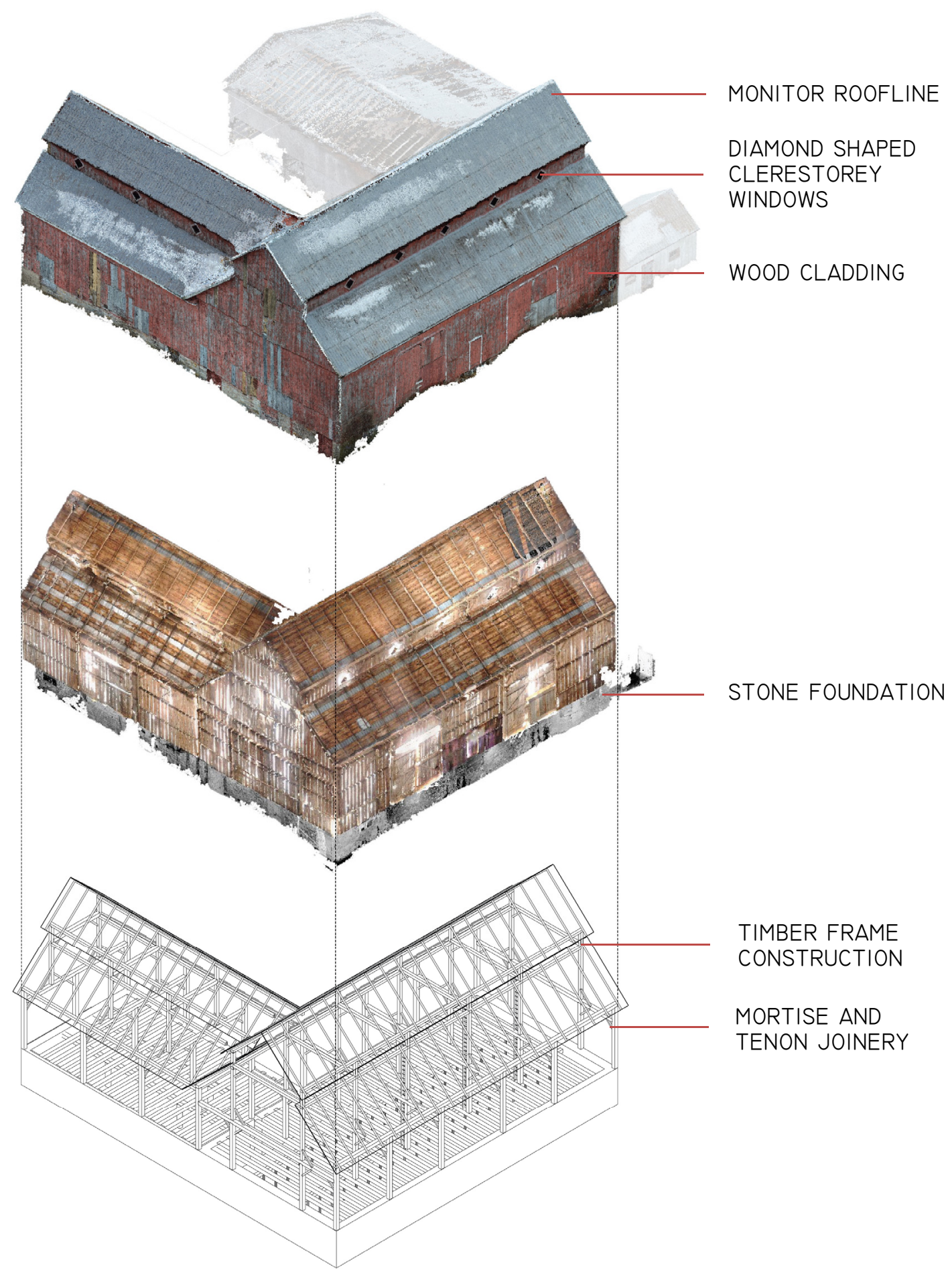

Illustration 3 Stacked axonometric drawing: locating character defining elements. 


\subsection{Current Reality}

"In the best of all worlds, respect for the cultural landscape as a common resource and as part of the common wealth would be so strong that heritage legislation would not have to exist" 27

There are several policies and measures in place to try to protect significant heritage properties and structures, including the Ontario Heritage Act, the City of Ottawa Official Plan, the Standards and Guidelines for Conservation of Historic Places in Canada, and more. Unfortunately, not even formal heritage designation is always enough to protect these significant properties; the only way to truly to ensure protection of our built heritage is through education and respect for the value of the stories and cultural energy these properties hold. Heritage values, especially intangible values, are exceptionally difficult to justify to economically driven developers; however, curious enough, many developers use heritage as a selling point to attract buyer. For example, the Hazeldean development is conveniently titled "Bradley Commons", a superficial connection to the heritage of the place without the effort to conserve any physical tie to the architecture or landscape. Without approaching the sensitive political situation surrounding this property, I will briefly discuss the current development plan and physical condition of the Bradley-Craig barn as it sets the scene for my alternative proposal. The Intent of this thesis is not to criticize the current development approach, but to propose a concept for adaptation which is more sensitive to the intangible heritage values and respect for the architecture of the barn.

\subsubsection{Development Plan}

Heritage designation is put in place to protect buildings and landscapes which help to paint the picture of our past. The Provincial Policy Statement (PPS), last updated in 2014, outlines land use, development planning, and resource management on a provincial scale. Section 2.6.1 of the PPS states that "significant built heritage resources and

\footnotetext{
27 Thomas F. McIlwraith, Looking for Old Ontario (Toronto: University of Toronto Press Ltd, 1997), 330.
} 
significant cultural heritage landscapes shall be preserved" ${ }^{28}$. On a City scale, land development is guided by a planning document known as the City of Ottawa Official Plan. Sections two and four of the Official Plan provide guidance for the conservation of Cultural Heritage Resources. The Official Plan understands heritage as:

" a crucial aspect of the City's planning and infrastructure. It has the power to transform mundane daily experiences into a deeper understanding of where we have come from and enhances our quality of life by engendering an appreciation of local identity and shared community." 29

Unfortunately, economics and convenience often compete with protection of such heritage assets, as was the case with the Bradley-Craig barn. In 2016, regardless of heritage status, and after much controversy, the developer was granted permission to relocate this barn from the Bradley-Craig farmstead to a location approximately twenty kilometers away. Although the physical structure and appreciation for the traditional craft would be conserved, the barn would lose all contextual significance associated with its placement on the original site. Fortunately, in January of this year, the decision was announced that the barn will be retained on its original site and integrated into the new commercial context. The exact approach to this development is not yet publicly known; however, commitment to incorporate the structure into the new community plan opens the possibility to create a thoughtful and integrated design, feeding off of the intangible heritage of the barn.

The land of the old Bradley-Craig farmstead is currently being developed under the Fernbank community design plan. Please note just a sample of the guiding principles as set out for this plan: "maintain and respect the integrity and unique character of existing communities", "create distinctive livable neighbourhoods", "create a 'heart' for the

\footnotetext{
28 “2014 Provincial Policy Statement,” Ontario.ca Planning Act (April 30, 2014), 29. http://www.mah.gov.on.ca/AssetFactory.aspx?did=10463

29 “Official Plan,” City of Ottawa, May 2003. https://ottawa.ca/en/city-hall/planning-and-development/ official-plan-and-master-plans/official-plan
} 
community", and "create an environmentally sustainable community" 30. Without going into further detail, I hope it is already clear that adaptation of this heritage barn provides a unique opportunity to fulfill all of these principles and more.

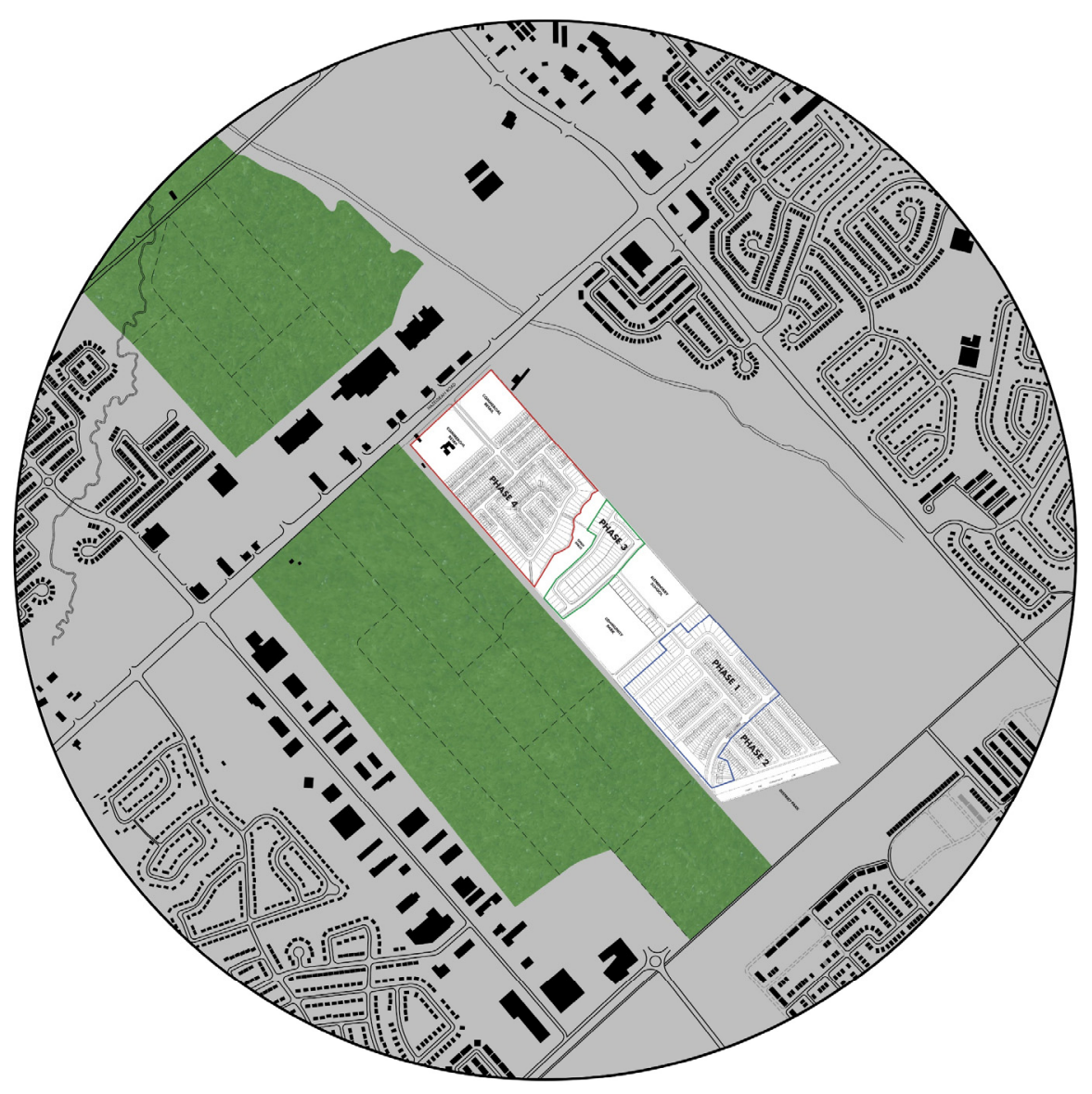

PROPOSED

Illustration 4 Surrounding land use under the Fernbank Community Design Plan.

\footnotetext{
30 "Fernbank Community Design Plan," City of Ottawa, accessed April 1,2018. https://ottawa.ca/en/cityhall/planning-and-development/community-plans-and-design-guidelines/community-plans-andstudies/community-design-plans/fernbank-community-design-plan
} 


\subsubsection{Physical Condition}

In 2010, The office of John G. Cooke and Associates Limited was contracted by Robertson Martin Architects to determine the condition of the barn structure and to assess the potential for adaptive re-use ${ }^{31}$. The findings of Cooke's report stated,

"From a structural perspective, the building is in generally acceptable condition overall, and items of concern are mostly localized in nature. At the time of this review, no global instabilities or excessive deformations were observed that would indicate that the structure poses a threat to the public or that it could not be adapted for re-use" 32

Localized repairs of deteriorated and damaged wood members are required, as well as in kind replacement of severely deformed members. Considering the historic load requirements of the barn, it is noted that the structural capabilities should be more than adequate for public assembly and retail use, as required by the Ontario Building Code. Cooke also noted considerable deterioration of the stone foundation, including deteriorated and debonded mortar. He further noted that lack of use and/or heating of the building will only accelerate the deterioration due to increased freeze, thaw effects. Cooke recommended repairs to the stone foundation, including removal of poured concrete at the corners, full raking out and repointing of mortar joints, and replacement of missing or severely damaged stones ${ }^{33}$. Such recommendations are typical of an historic structure and can be realistically integrated into the adaptation project.

Laser scanning, photogrammetry, and photography were employed to document the current condition of the structure. Within the laser scans, physical deformations are visible, unveiling a structural reality which is otherwise impossible to accurately document. Through exterior photogrammetry, I have produced high quality orthographic images of all elevations, allowing for accurate condition assessment of the exterior envelope. Still photographs are used to document specific details and conditions.

\footnotetext{
31 John G. Cooke \& Associates Ltd., "Historic Barn Condition Survey: Craig Family Farm, 590 Hazeldean Road, Kanata," January 6, 2010, 1.

${ }^{32}$ Cooke \& Associates Ltd., "Historic Barn Condition Survey", 3.

${ }^{33}$ Cooke \& Associates Ltd., "Historic Barn Condition Survey", 3.
} 


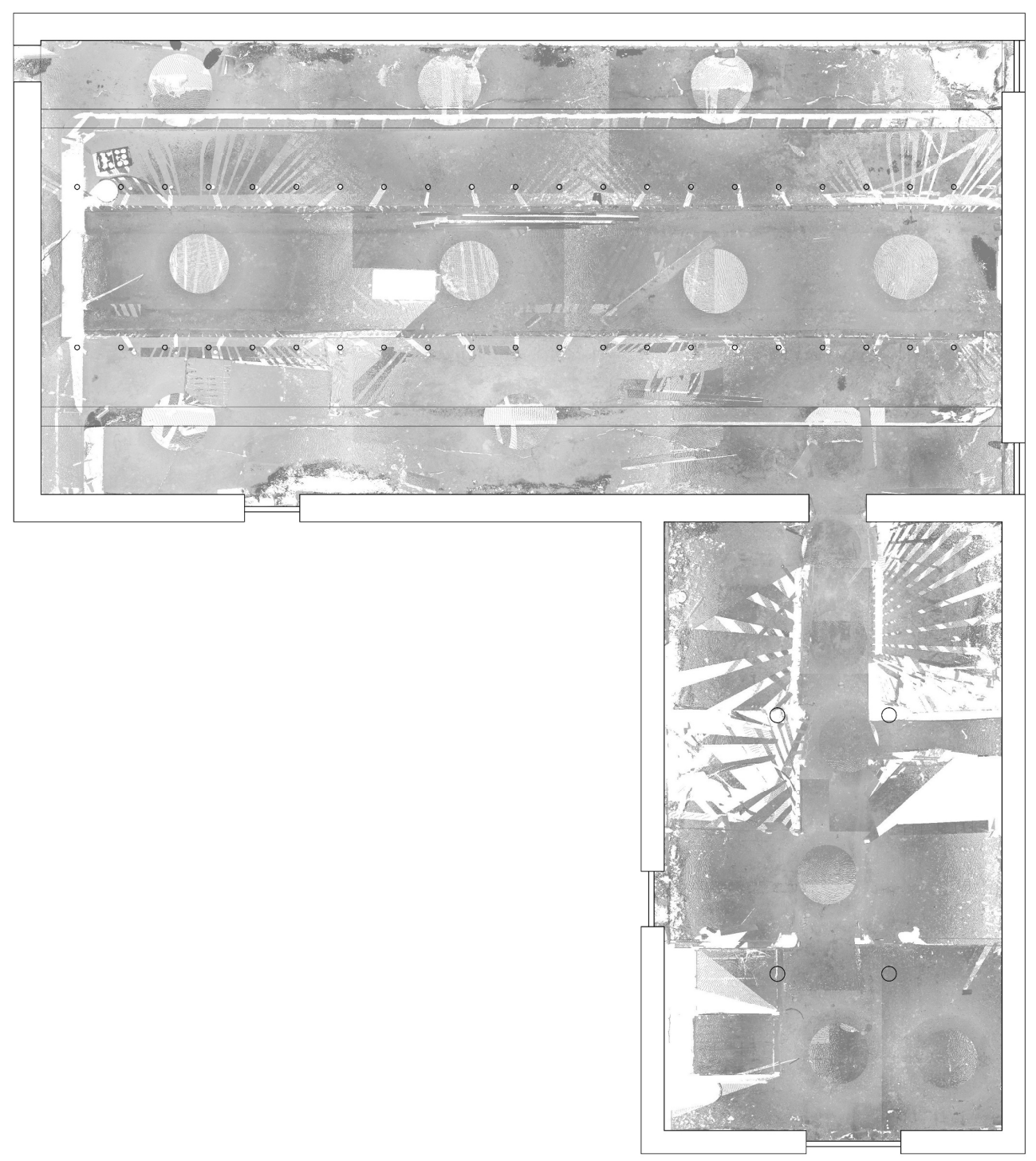

Illustration 5 Lower level plan, produced from laser scan data. 


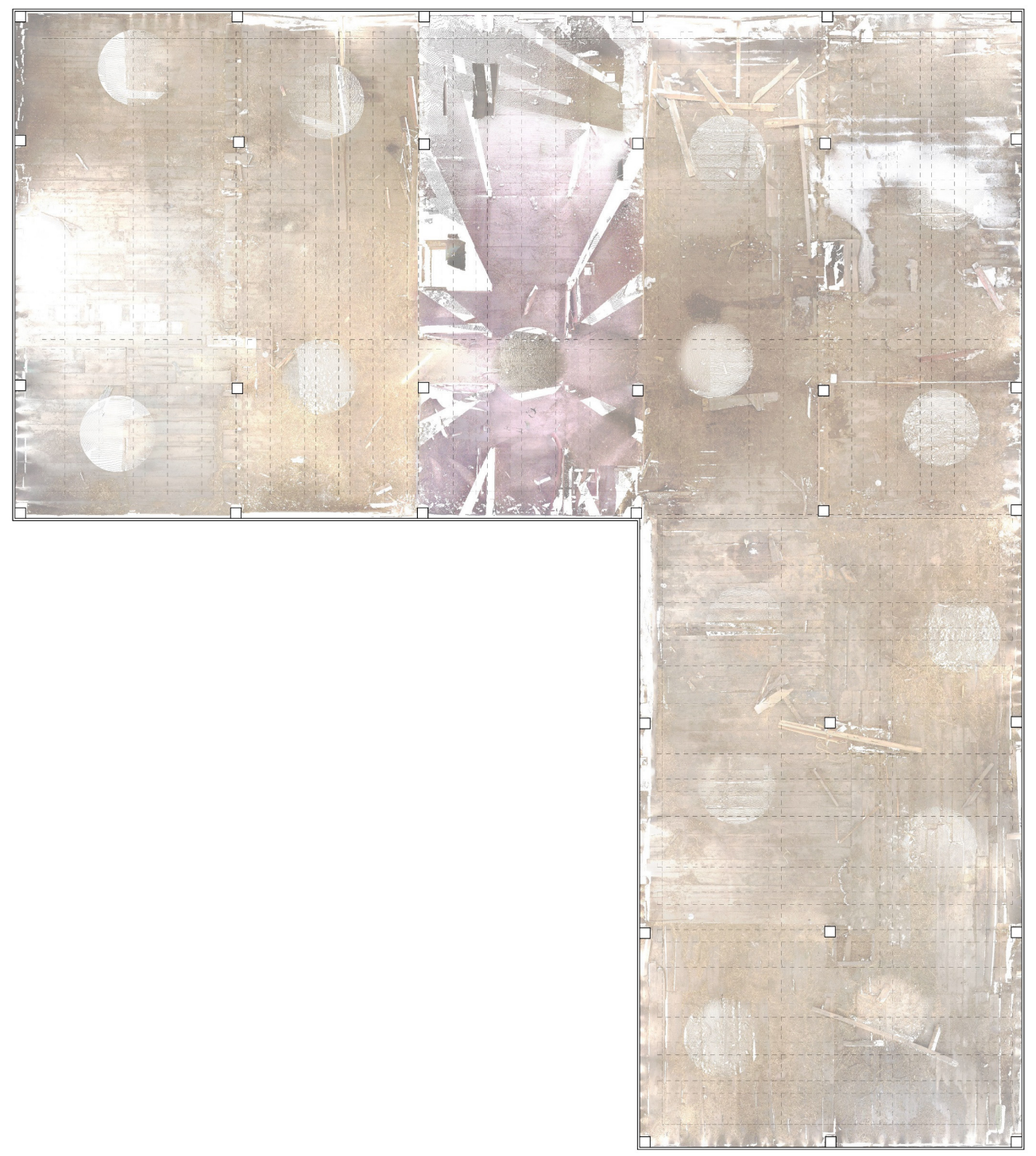

Illustration 6 Main level plan, produced from laser scan data including section and elevation key. 


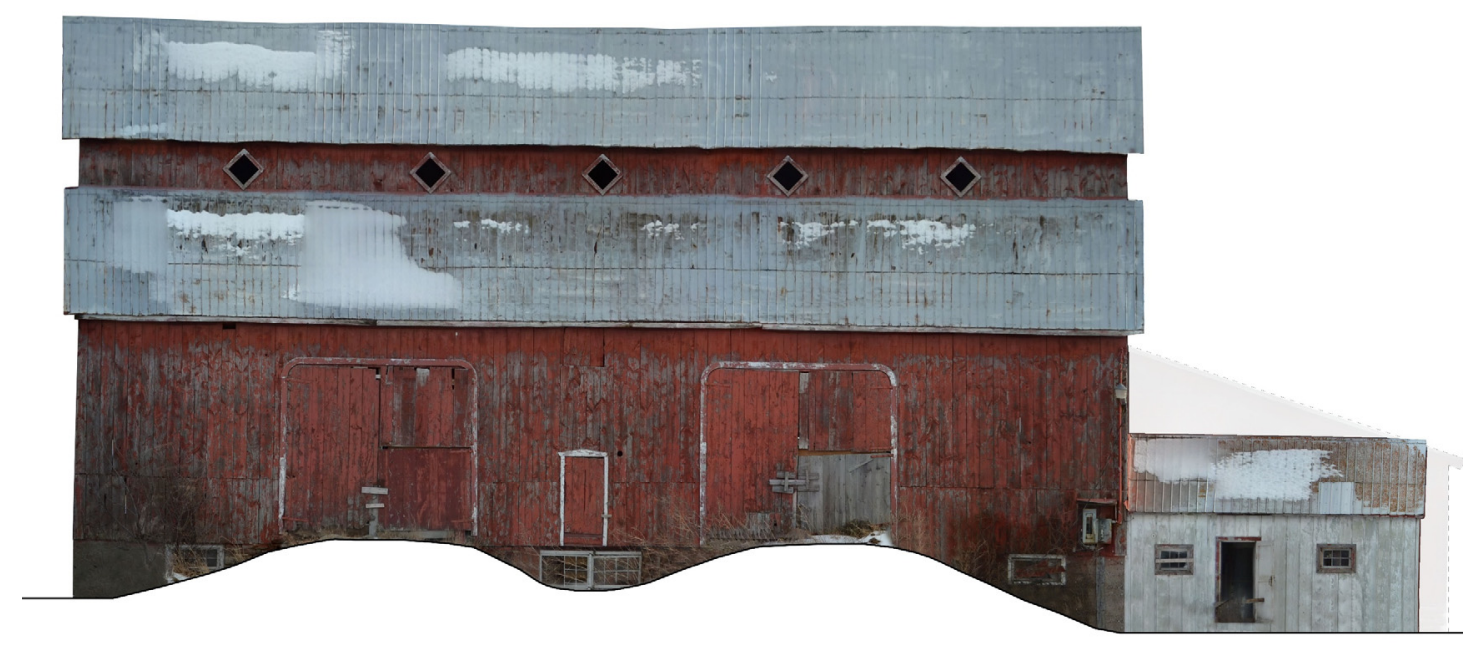

Illustration 7 North elevation, produced from photogrammetric data.

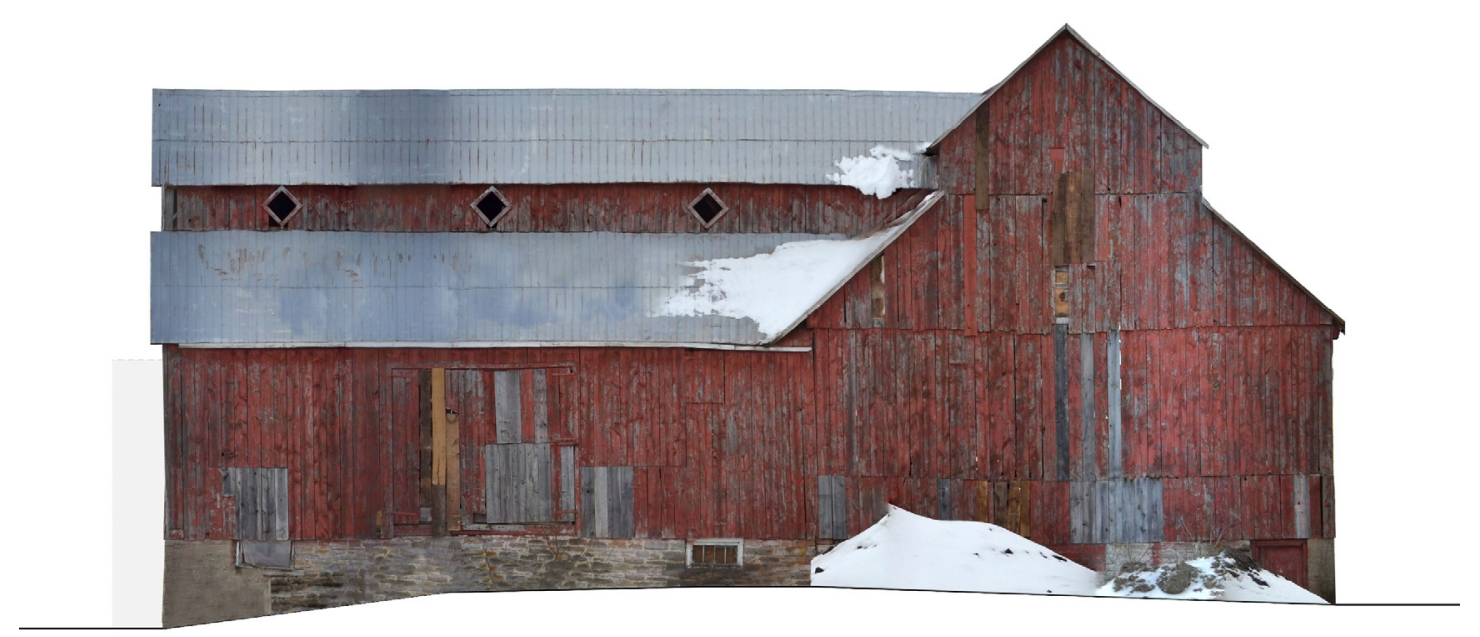

Illustration 8 East elevation, produced from photogrammetric data. 


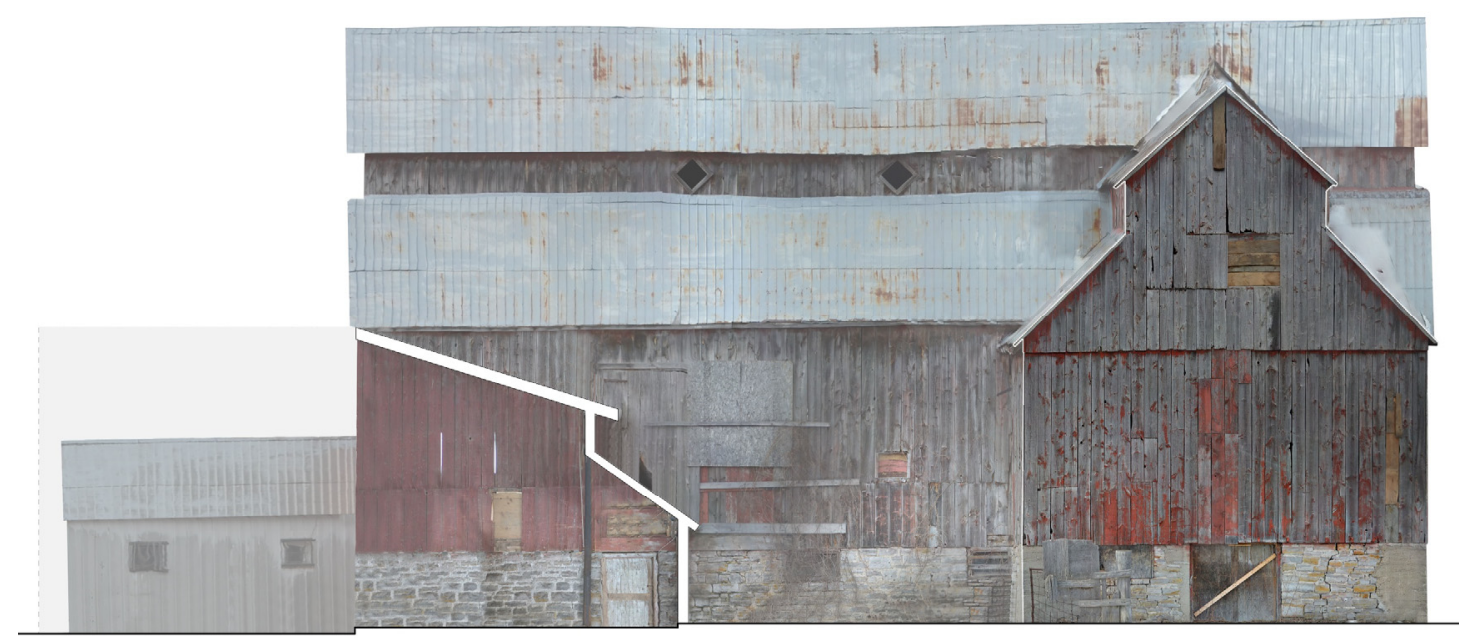

Illustration 9 South elevation, produced from photogrammetric data.

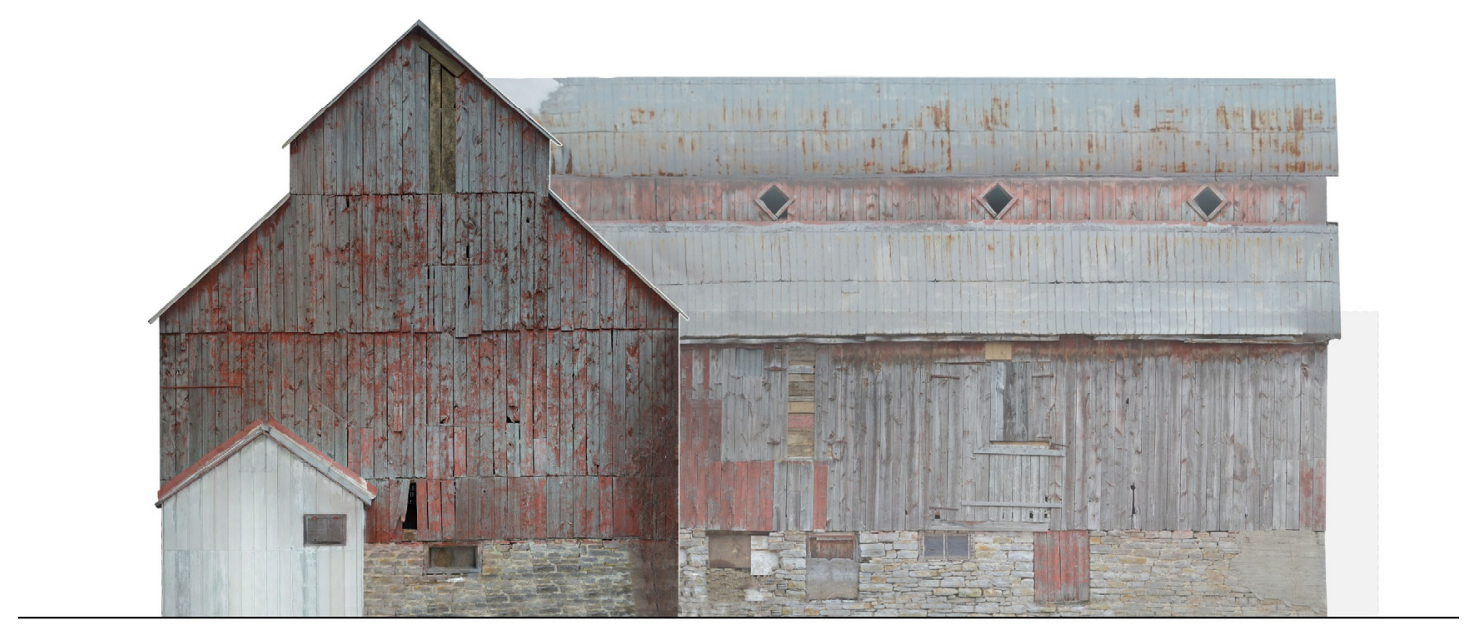

Illustration 10 West elevation, produced from photogrammetric data. 


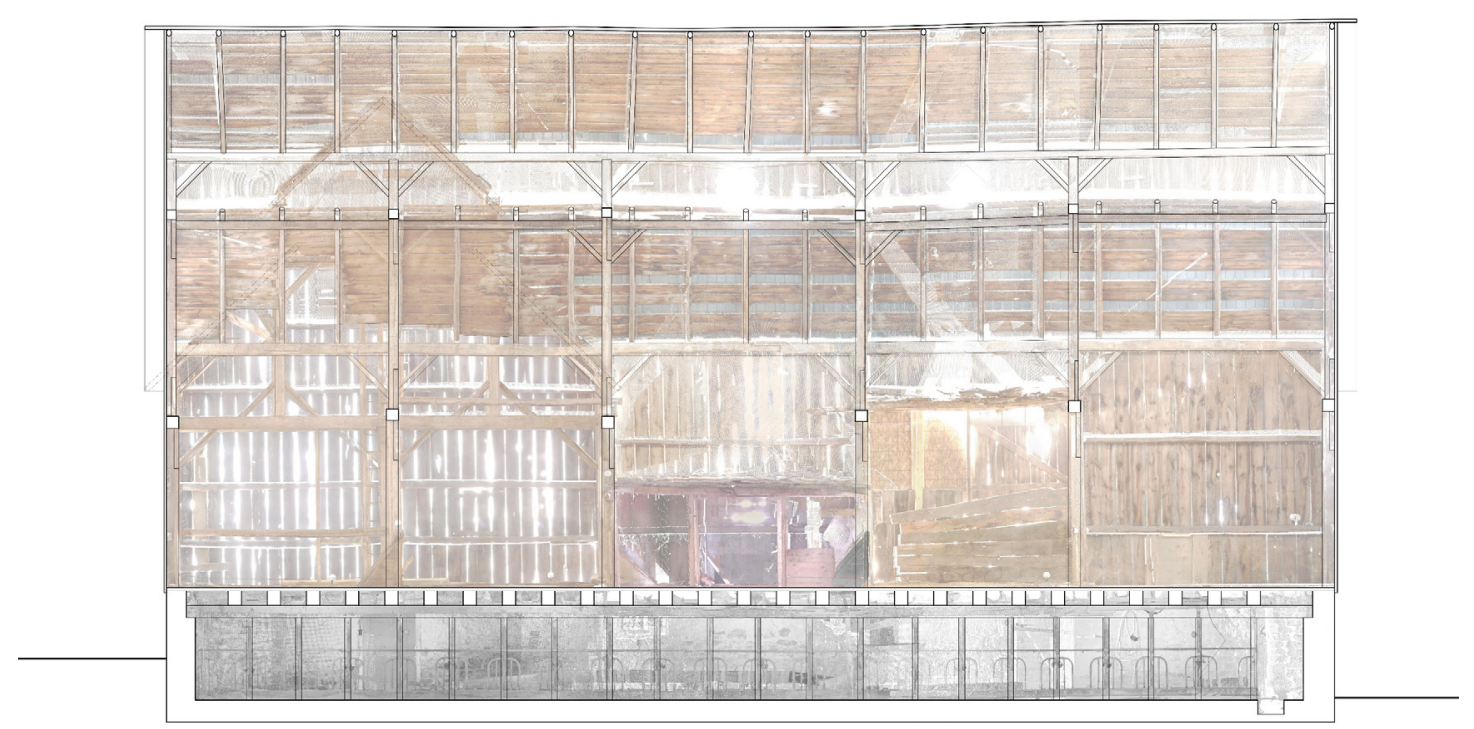

Illustration 11 Section $1 \mathrm{~A}$ - east-west section, produced from laser scan data.

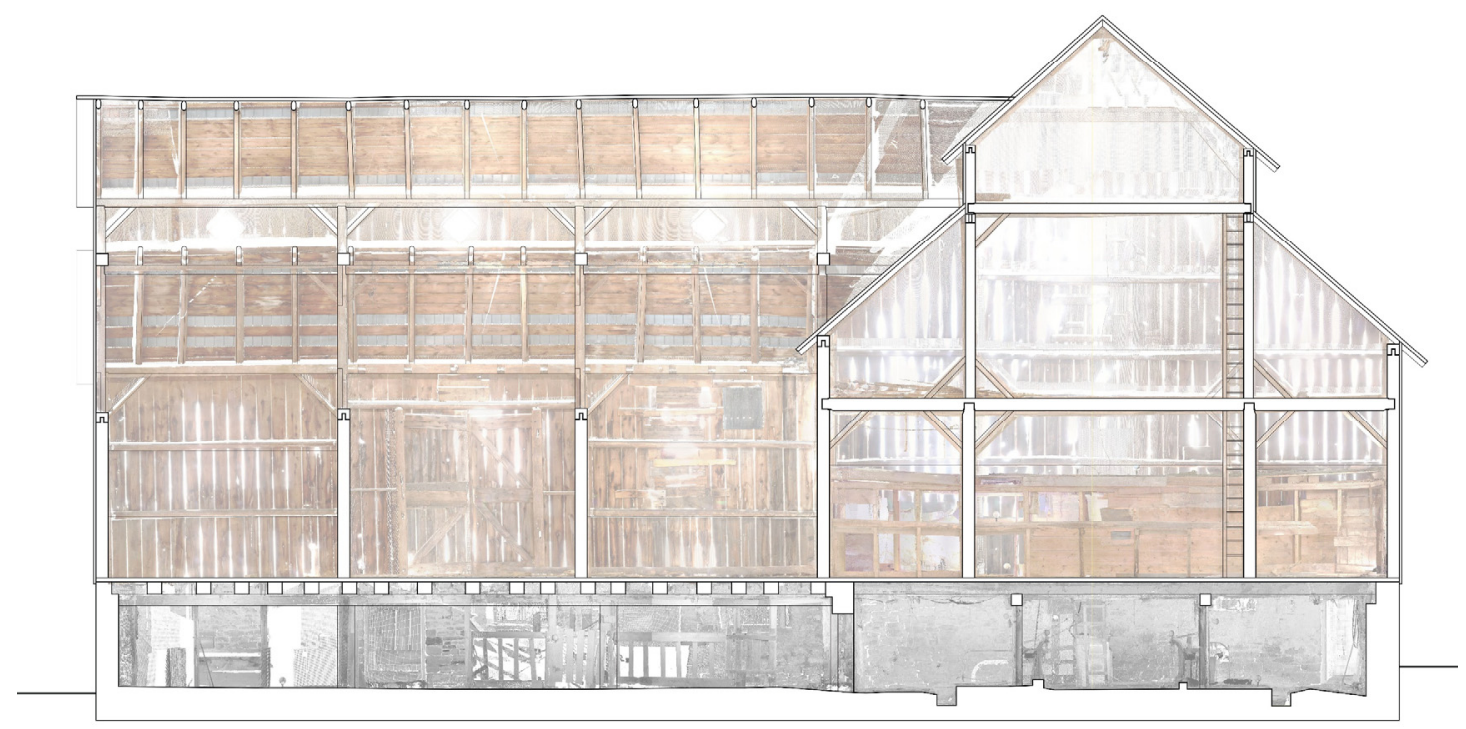

Illustration 12 Section $2 \mathrm{~A}$ - north-south section, produced from laser scan data. 


\subsection{The Intangible History of the Barn}

The Bradley-Craig barn is a physical expression of the settlement, clearing, and establishment of rural Ontario. The intangible cultural history of the barn includes a story of almost 150 years of technical and cultural development, the distinctive beauty of traditional timber craftsmanship, and community evolution from rural to suburban.

\subsubsection{Story: The Evolution of the Barn and Cultural Landscape}

The Bradley-Craig barn is a bank style barn, "a two-level barn with access to the upper level by way of a hillside or ramp" ${ }^{34}$. The bank style barn was developed from a desire to accommodate all of the farmers needs under one roof: shelter for animals, storage for crops and equipment, a milking parlour, et cetera. As such, the design is ideal for the mixed-use farm and large dairy operation of the Bradley-Craig barn. The form and construction of this structure represent a time in agricultural history when farming became more prosperous, and farmers were able to replace their original log structures with more elaborate and technically advanced timber-framed barns ${ }^{35}$. Illustration 13 shows a historic photograph from the early 1890s, in which the south-east wing of the barn is still of original log construction, before being replaced with the timber addition. The Bradley-Craig barn also exhibits many innovative agricultural technologies and features of the time, such as, ramps, rope and pulley systems, efficient milking parlour design, and others ${ }^{36}$. Due to the innovative design and labour saving technologies, the farm became a model for dairy farms across Southern Ontario ${ }^{37}$.

\footnotetext{
34 Elric Endersby, et al., Barn: Preservation \& Adaptation (New York: Rizzoli, 2014), 264.

35 Commonwealth Resource Management. “A Cultural Heritage Impact Statement: Bradley/Craig Barn Demolition \& Relocation 590 Hazeldean Road, Ottawa” September 2015, 15.

36 Commonwealth Resource Management. “A Cultural Heritage Impact Statement,” 16.

37 Commonwealth Resource Management. "A Cultural Heritage Impact Statement,” 16.
} 


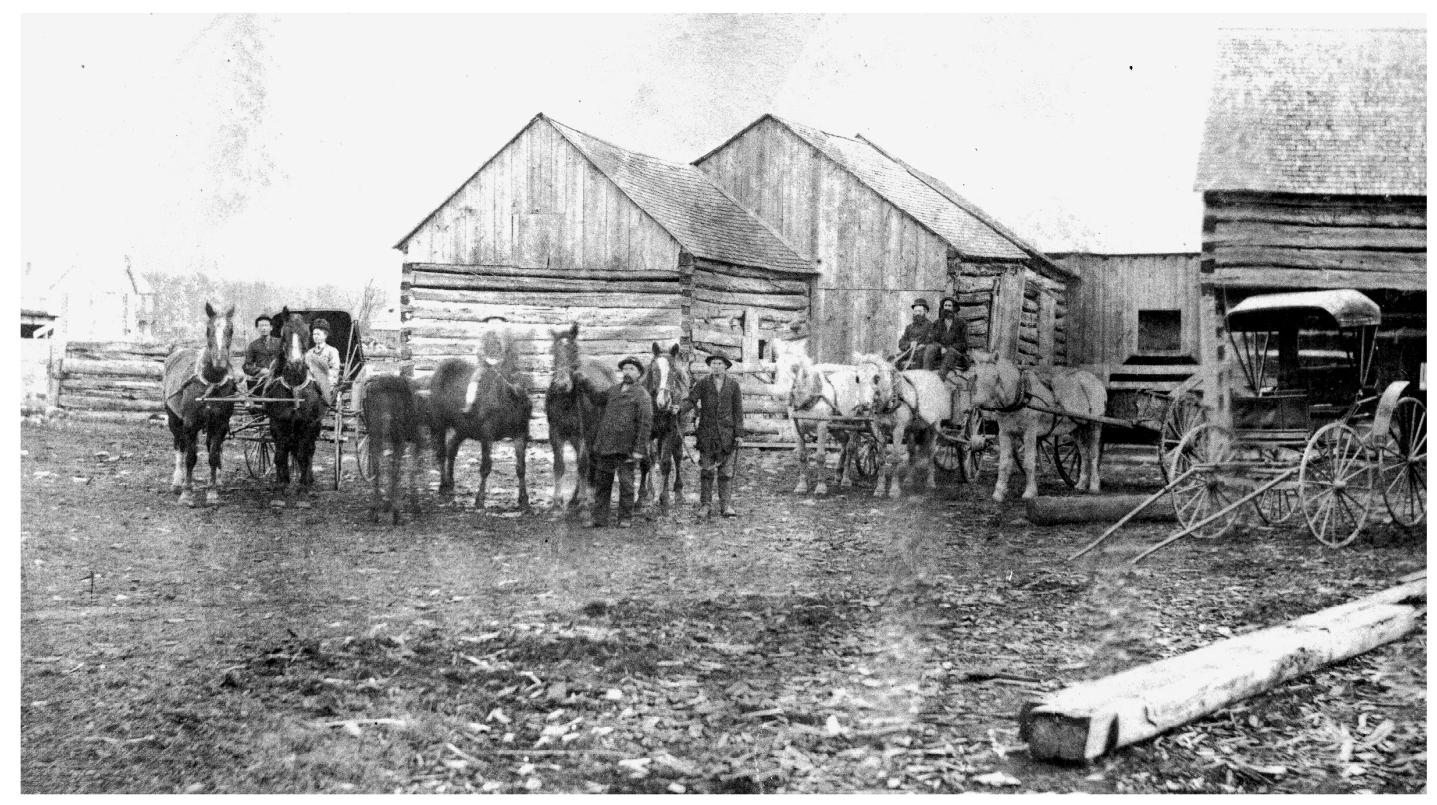

Illustration 13 Early 1890s photography of Bradley-Craig barn, south elevation.

(Courtesy of the Goulbourn Historical Society collection, donated by Mrs. John Clifford Bradley).

The dissociation between the farmstead and the rest of the farm land diminished the value of the barn and the readability of the structure as part of the cultural context. As stated in the Cultural Heritage Impact Statement, "These buildings [the barn and the farmhouse], their spatial relationship, and the views between these buildings are the remaining components of what had been a complex and complete system" ${ }^{38}$. Using the site of my case study, I have analyzed the evolution of the surrounding land over the past 150 years and the dramatic impact on the cultural landscape. Looking at Illustration 14 below, one can clearly see the decrease in agricultural land and the rapid suburban development which has taken place, specifically over the past 25 years. The layered mapping allows us to view the change as a moving and almost living evolution, with the ghosts of lost buildings visible below the surface. This idea speaks to the concept of a living landscape as a palimpsest, as proposed above.

38 Commonwealth Resource Management. “A Cultural Heritage Impact Statement: Bradley/Craig Barn Demolition \& Relocation 590 Hazeldean Road, Ottawa” September 2015, 11. 
The fight to mitigate the cultural effects of suburbanization can further benefit from the stories and memories of the past to add rootedness to such communities. "Memory in the landscape builds on the interplay of decline and recovery ... The same argument has been invoked by heritage conservation groups determined to see that suburbs do not totally obliterate the farming landscapes they are built on" ${ }^{39}$. Cultural histories are non-linear and ambiguous; as noted, cycles of decline and recovery are critical to the layers of life that make our cultural landscape as profound as it is today. Adaptation of barns, and integration into our evolving communities adds but the next layer to this story.

${ }^{39}$ Thomas F. McIlwraith, Looking for Old Ontario (Toronto: University of Toronto Press Ltd, 1997), 316. 


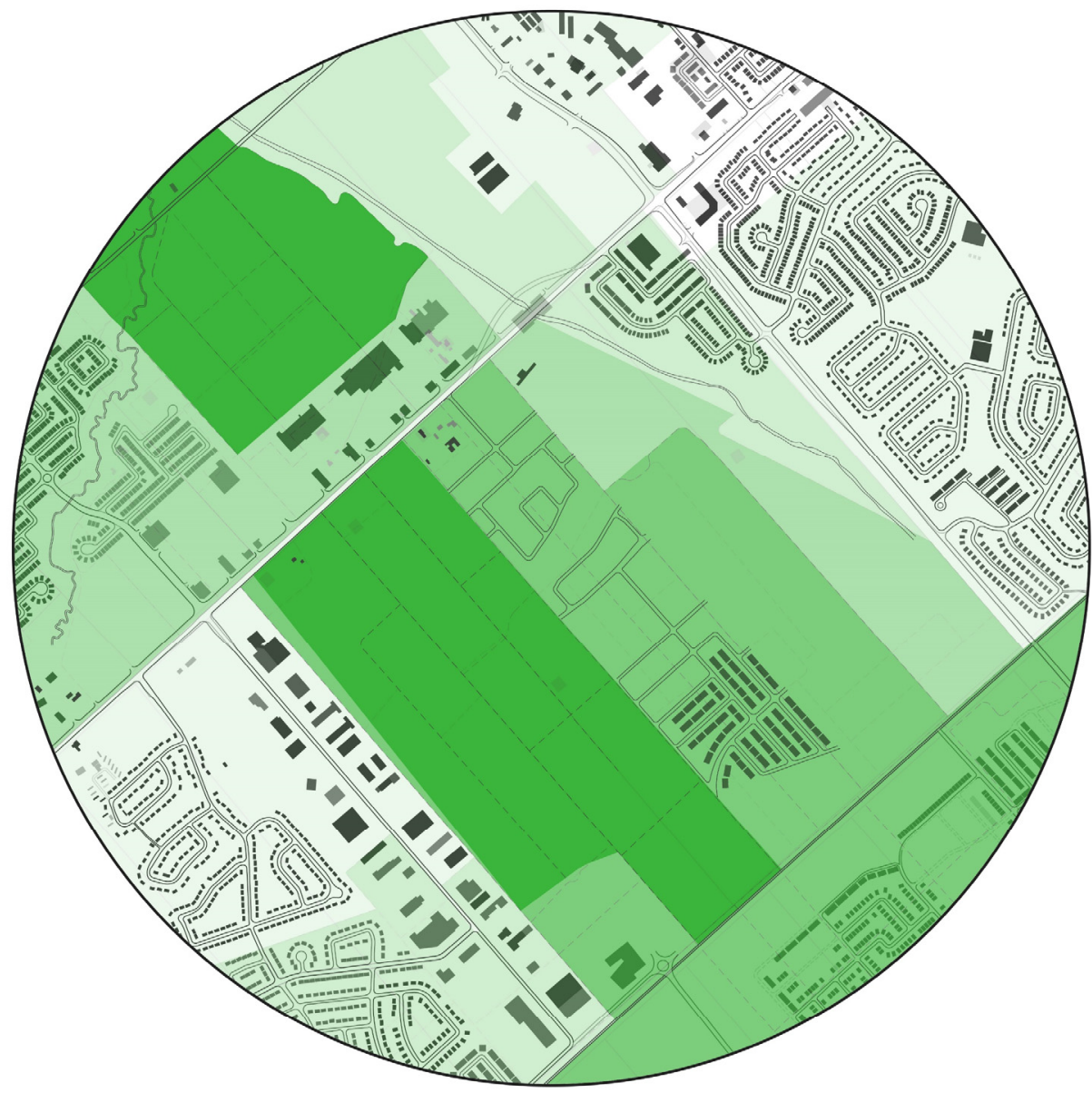

PROPOSED

Illustration 14 The evolving landscape of Hazeldean Road (1879 - 2017) 


\subsubsection{Craft: Physical Construction + Tangible Beauty}

"As barns go, she is a lovely one - tall, double-roofed, with gorgeous bones and a necklace of little diamond windows." 40

The large ' $L$ '-shaped barn is an impressive piece of architecture. The original north portion of the barn was built in 1873 by respected local craftsman John Cummings (1831-1887), and assisted by local farmers and apprentices, in the communal effort of a barn-raising bee ${ }^{41}$. The precise date of construction of the south-east addition is unknown; however, from photographic evidence (Illustration 13) it appears that the addition was built post-1890. A timber framed barn is constructed using a series of bents - two-dimensional assemblies of vertical posts and horizontal beams. Each of said assemblies are joined together with additional horizontal members - a sill plate at the ground or foundation, mid-level girts, and a top plate at the eave. Additional support is achieved through diagonal bracing where two or more members come together.

Connection conditions within a timber frame are critical to the strength and longevity of the structure; the precision and accuracy of the mortise and tenon connections speak to the skill and experience of the builder and has a direct correlation to the integrity of the building. The awe factor of these structures is achieved through sheer scale and full exposure of this beautiful craft, as it does not get covered up in the final building.

"Such beautiful unadorned vernacular architecture is living proof of the amazing craftsmanship of this era ... The barns ... speak for themselves as ageless artistic works of great power, built for the millennium." 42

\footnotetext{
${ }^{40}$ Kelly Egan, "After 140 years, it took heritage nod to make barn shaky," The Ottawa Citizen, May 19, 2014, http://ottawacitizen.com/news/local-news/after-140-years-it-took-heritage-nod-to-make-barn-shaky ${ }^{41}$ Marguerite Evans, "The Vulnerable Bradley/ Craig Hazeldean Property" The Historical Society of Ottawa News, no. 143 (January 2014): 8.

42 John Radojovic, Barn Building: The Golden Age of Barn Construction, as quoted in Commonwealth Resource Management, "A Cultural Heritage Impact Statement: Bradley/Craig Barn Demolition \& Relocation 590 Hazeldean Road, Ottawa,” September 2015, 18-19.
} 


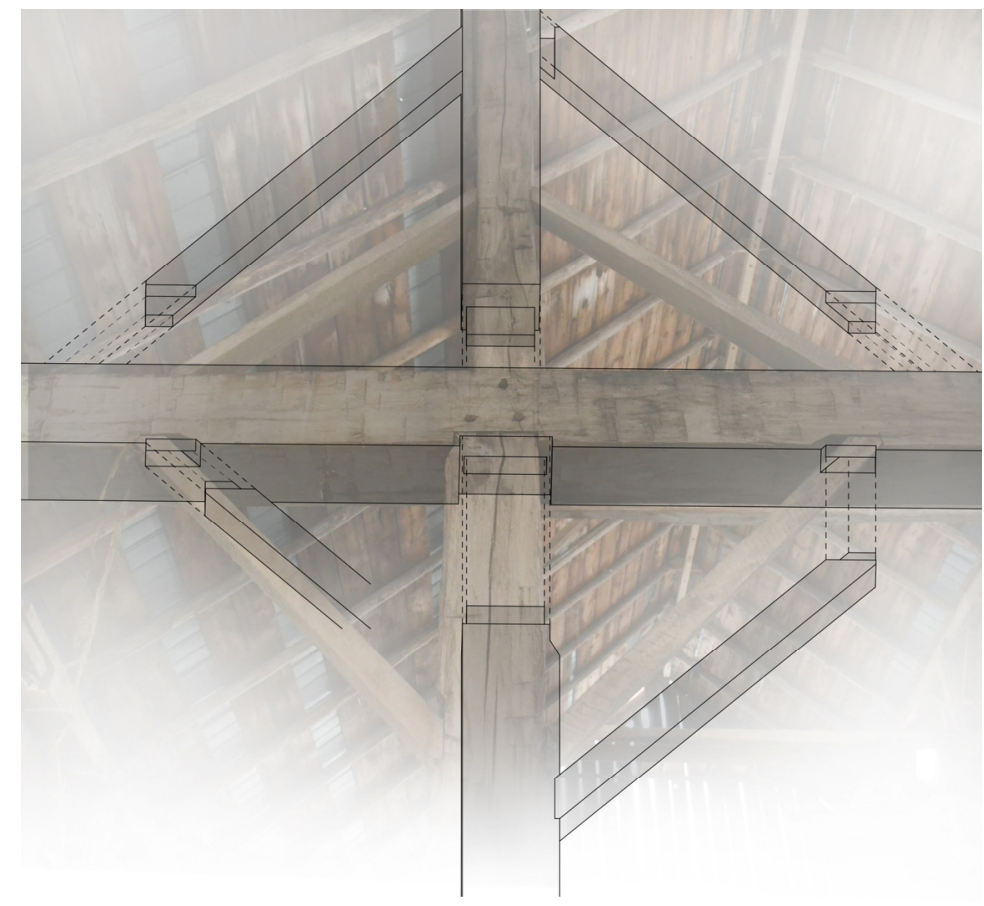

Illustration 15 Mid-span timber connection, as found in the Bradley-Craig Barn.

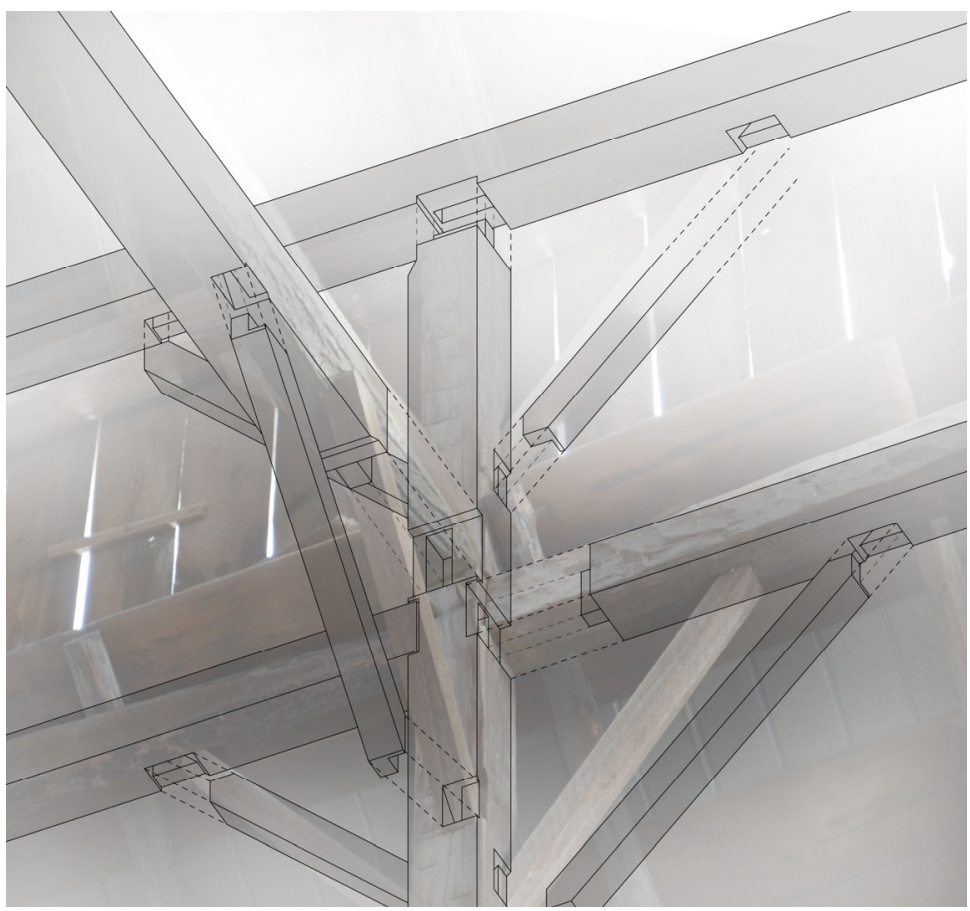

Illustration 16 Exterior timber connection, as found in Bradley-Craig Barn. 


\subsubsection{Community: Cultural Significance}

The large red barn once stood as a landmark on Hazeldean Road, visible from both directions and central to the agricultural functioning of this rural community; however, with the encroachment of commercial and domestic development, recognition of the barn as a landmark structure is becoming lost ${ }^{43}$. The Bradley-Craig barn is described as "the quintessential example of the traditional pioneer farm; a form that was repeated throughout Ontario" ${ }^{44}$. Settlement of this land was part of the movement to inhabit and defend vulnerable countryside following the war of 1812; this is significant to the immigration of farmers, such as the Bradley family. Joshua Bradley was granted his parcel of crown land in 1824 alongside his brother Jacob. In the early $20^{\text {th }}$ century, John Clifford Bradley operated a dairy out of the small north-west addition on the barn ${ }^{45}$. Sleigh or wagon transported milk, directly from the farm into Ottawa for delivery ${ }^{46}$. The new design shall pay homage to this part of the story as it is critical to the importance of the dairy farm as connected to the surrounding community.

The reciprocal bee was not only critical to the physical construction of individual barns, but from a social perspective, the bee also became integral to the structuring, operation, and definition of neighbourhoods ${ }^{47}$. At the time of first settlement, communities were composed of families from numerous cultural backgrounds. Working together towards common goals and needs brought people of different cultures, genders, ages, and social statuses together, "the bee provided the mechanism for social integration and bonding", to create a sense of identity and belonging ${ }^{48}$. As understood, physical proximity played a greater role in creating a neighbourhood than cultural identity; however, Wilson identifies the importance of interaction, social support, and

\footnotetext{
43 Commonwealth Resource Management, “A Cultural Heritage Impact Statement: Bradley/Craig Barn Demolition \& Relocation 590 Hazeldean Road, Ottawa," September 2015, 5.

${ }^{44}$ Commonwealth Resource Management "A Cultural Heritage Impact Statement," 15.

${ }^{45}$ Marguerite Evans, email sent to author, April 1, 2018.

${ }^{46}$ Marguerite Evans, email sent to author, April 1, 2018.

47 Catherine Anne Wilson, "Reciprocal Work Bees and the Meaning of Neighbourhood," Canadian Historical Review 82, no. 3 (September 2001): 1.

${ }^{48}$ Catherine Anne Wilson, "Reciprocal Work Bees and the Meaning of Neighbourhood," Canadian Historical Review 82, no. 3 (September 2001): 6.
} 
interdependence as critical to defining a neighbourhood, or a community ${ }^{49}$. The BradleyCraig barn, built by the coming together of a community - in what was the reciprocal bee - may once again bring the community together and create a sense of belonging. In celebrating the public history of the barn and opening the building up for communal use, a sense of rootedness and identity may be achieved.

${ }^{49}$ Wilson, "Reciprocal Work Bees and the Meaning of Neighbourhood," 1. 


\title{
3 Chapter: ICH - a Strategy for Design
}

\author{
"we should see architectural residue from the past as a repository of \\ vast physical, human, and cultural energy" 50
}

This thesis explores how intangible cultural heritage can be used as a conceptual tool in guiding future design and adaptation. I argue that the Bradley-Craig Barn provides a unique opportunity to set this development apart from any other; heritage buildings can act to inspire architects to think outside of the box and to raise the bar on suburban design. The frame of the Bradley-Craig barn creates large open spaces, which present endless opportunities for flexible interventions. This study explores the intangible qualities of story, community, and craftsmanship. Story, represents the conceptual history of the structure, which can be read through the physical evolution of the barn, and the visible evidence of use and time. Community, represents the contextual history, the role of the barn in the broader cultural context throughout time. Lastly, Craftsmanship, represents the technical history, the physical evidence of quality timber craft, particularly in the original joinery and the hand-hewn timbers. The following schematic design will expose the potential to use these three intangible qualities to define the role and form of the Bradley-Craig barn in the future development.

\subsection{The Story}

The story is what remains when the people have gone, and activities have ceased, the residue of life and time. In this barn, the story includes the Bradley family who worked from sun up to sun down to tend their farm and feed their family. Most recent inhabitant, Norma Craig (nee Bradley), who was born and raising on this farm, spoke to CBC News about her fond memories, "I can see milking time when we used to do it by

\footnotetext{
50 Vani Bahl, "Ethics of Adaptive Reuse". Architecture Week (2005) accessed January 08, 2018, http://www.architectureweek.com/2005/0518/building_1-2.html.
} 
hand, and squirting the milk in the cat's mouth and she'd lick it off her face" ${ }^{51}$. The goal of the design is to communicate these stories and experiences. As expressed, the story of a building is contained within the material components. If one looks hard enough, the physical signs of these memories remain. Author Eric Arthur depicts the importance of tactile memory:

"Everyone has experienced the pleasure, tactile as well as visual, of chairs, chests, and handrails ... Fewer have enjoyed the same experience in the barn. Many a threshing floor has the polish of a ballroom floor from the old days of flailing wheat, and all the timbers within wagonload-height have taken on a honey colour, and all arrises have been softened ... by the rubbing of hay, straw and sheaves from harvest of a century or more" 52

Integration of the historic threshing floor into the new design is critical to honouring the story of the barn. So much of the history of the barn can be read, through the marks on these boards: rusted out nail holes, punctures and dents from pitch forks, and the polished smoothness caused by threshing many years of grain and hay. The two-inch thick original threshing floor will be removed, brush cleaned, milled on one side to create a solid tongue-and-groove product which will then be reinstalled in the adapted space. A matte clear finish can be applied to the floor which will render the material practical for contemporary interior use, whilst retaining the signs of years of life. A successful adaptation should highlight the layers of life and time. Thus, the architect must make readable the past chapters and enable future generations to add their own story.

\footnotetext{
${ }^{51}$ Laurie Fagan, “'That's not progress': Stittsville farm's last inhabitant blasts developer's inaction,” $C B C$ New, January 30, 2018, http://www.cbc.ca/news/canada/ottawa/heritage-stittsville-farm-barn-richcraft1.4508684

52 Eric Arthur and Dudley Witney, The Barn: A Vanishing Landmark in North America (Toronto: M. F. Feheley Arts, 1972), 12.
} 


\subsection{The Community}

"[The area] begs to have the injection of the rural roots and nowunique farmstead, with its landmark barn preserved, if for no other reason than to provide a point of interest within this sameness [the bleak auto-oriented view which defines this stretch of the Hazeldean Road area]" 53

In his review of the cultural impact of moving the Bradley-Craig barn, heritage architect Mark Brandt addresses the potential which this barn holds to bring a unique identity to the developing area. Brandt goes on to point out the commercial potential of the property due to the unique character of the site, a distinctive "brand" to set this development apart and attract new businesses and customers ${ }^{54}$. However, to take full advantage of the cultural potential of this building, the adapted use must also have a public component. Private function, such as office space, does not take advantage of the full potential of the barn: to draw the public to the site, to draw potential buyers to the development, and to strengthen the identity of the community.

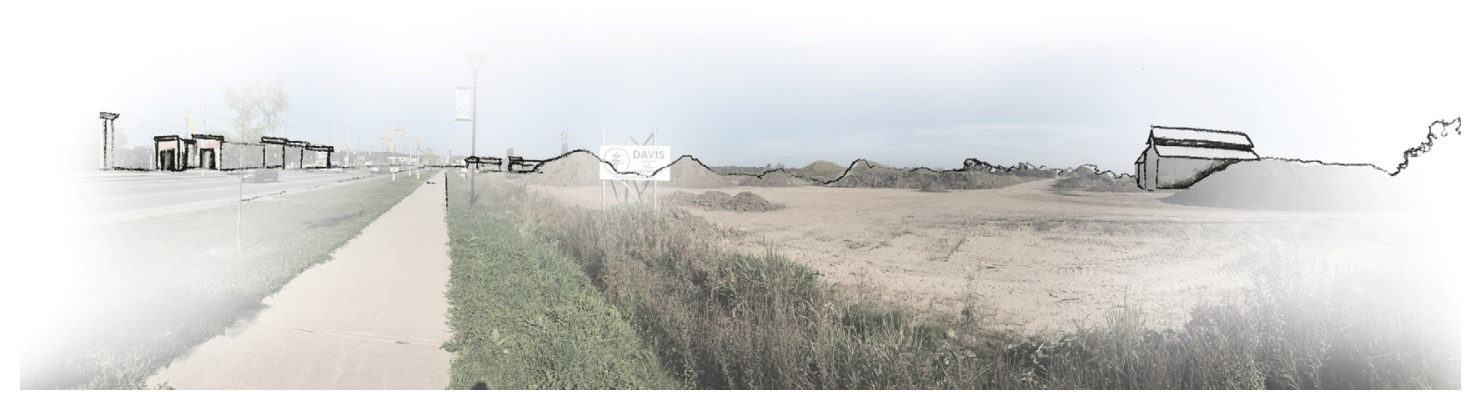

\section{Illustration 17 Site section sketch.}

\footnotetext{
${ }^{53}$ Mark Thompson Brandt, "Re: Bradley-Craig Barn and Proposed Property Development, 590 Hazeldean Road, Stittsville" MTBA review of application for demolition and relocation, January 22, 2016.

${ }^{54}$ Brandt, "Re: Bradley-Craig Barn and Proposed Property Development, 590 Hazeldean Road, Stittsville".
} 
As previously describes, suburban communities are both built on and centred around cars as the primary mode of transportation. McIlwraith describes how cars changed the perception and appreciate of the countryside, including people's experience of their surroundings ${ }^{55}$. "Walking permits intimate contact with places, and it provides the chance for pondering all the little things that add up to the lived-in world, and at a suitably deliberate pace. Walking is our best hope for increasing awareness of the human landscape that surrounds and embraces us" ${ }^{56}$. Walking and slowing down, may be the key to reconnecting us with our surroundings, and may once again give people a sense of place and belonging. This should be achieved be integration of walking paths, connecting the barn to the community.

Agricultural structures hold a long history of assuming new roles; with each change of season and technological advancement, barns were forced to adapt. Flexible programming can integrate temporary cultural activity into developing communities ${ }^{57}$. Such cultural activity may take the form of seasonal markets. Traditionally, the barn always functioned as a flexible, seasonal space ${ }^{58}$. Perhaps more accurately, the barn as the centre of rural culture, acted to bring a community together. The new program should do just that, provide a heart for a community which is increasingly divided. In contemporary society, physical fitness is one of the few activities which brings a community together. A multi-purpose fitness centre with flexible space for exercise equipment and fitness classes is an example of an appropriate use for the adapted barn space. Within this space people may appreciate the architecture which surrounds them and connect with their neighbours. Support spaces such as washrooms, change rooms, storage, and mechanical spaces can be located on the lower level - not shown in the plans below.

\footnotetext{
55 Thomas F. McIlwraith, Looking for Old Ontario (Toronto: University of Toronto Press Ltd, 1997), 15.

56 McIlwraith, Looking for Old Ontario, 16.

57 Johann Jessen and Jochem Schneider, "Conversions - the new normal," in Building in Existing Fabric: Refurbishment, Extensions, New Design, ed. Christian Schittich (Berlin, Basel, Boston: Edition Detail, Birkhäuser, 2003), 12.

58 Elric Endersby, et al., Barn: Preservation \& Adaptation (New York: Rizzoli, 2014), 10.
} 

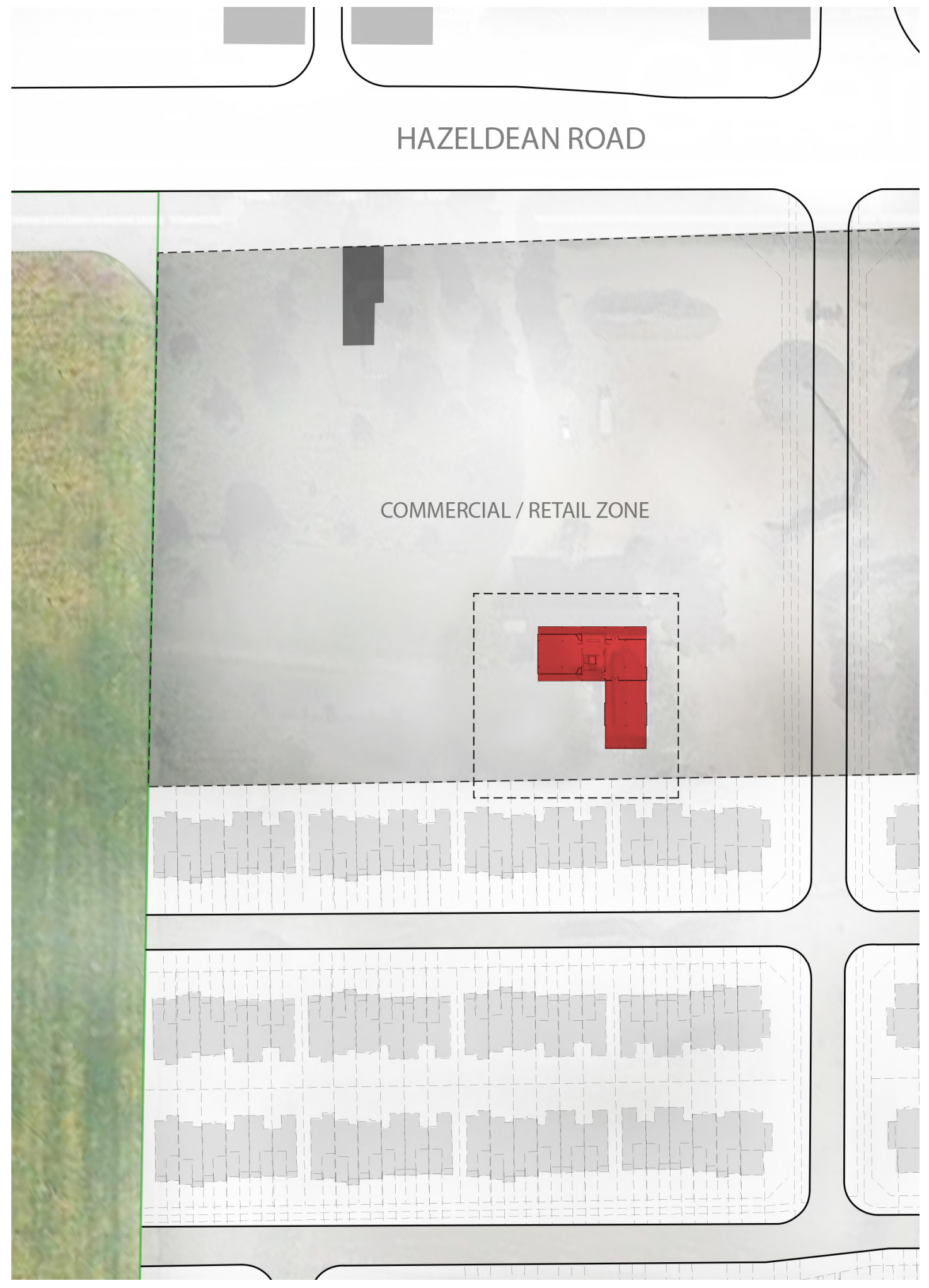

Illustration 18 Site plan - showing location of barn in broader development context. 


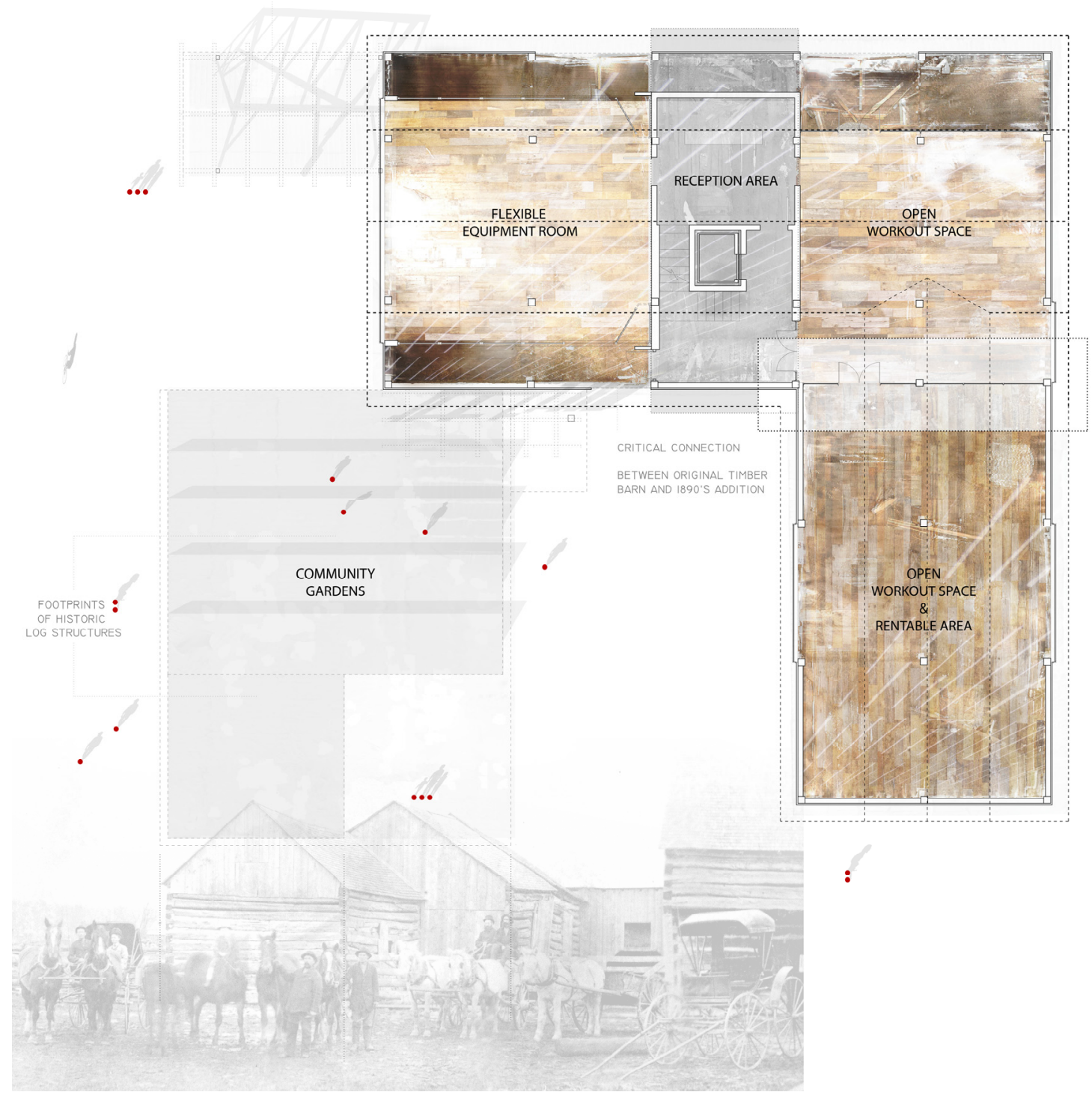

Illustration 19 Main level plan, showing new schematic design and adjacent context. 


\subsection{The Craftsmanship}

The tangible signs of hand-craft within the timber structure inspire curiosity and imagination; however, the timber frame is more than structure and stability, it is a poetic connection to both the past and the future. The new design should take advantage of the depth and history within the hand-hewn timbers, design ingenuities such as the clerestory windows, and the awe-inspiring factors of the grand scale of the structure and light filtration through the barn boards. Such features hold the essence of the barn and the story. Moreover, new features should be subordinate to the historic skeleton, thereby drawing focus to the beauty and craftmanship of the original barn. The design will highlight the permanence - in structural and poetic strength - of the timber frame and the traditional craftsmanship of the barn.

The craftsmanship signatures, visible within this barn, include the hand-hewn timbers and timber joinery. Moments of connection, moments to pause, and appreciate the beauty of the structure must be captured; the new intervention will act to frame these critical heritage components through light and purposely placed glazing. Sliding bolted connections between the steel flange and frame allow for the glazing to flex with the natural movement of the timber frame. Typical conservation techniques such as full repointing of the stone foundation, fresh red paint to the exterior cladding, and a new tin roof, and other critical actions to protect the structure will be employed; such treatment is consistent with historical maintenance of the structure. How to insulate the structure against the Ottawa climate without losing the atmosphere created by the sunlight filtering in through the gaps in the boards is a challenge in this project. This is deal with by constructing a new glazed wall inset from the historic structure. In other areas, exterior walls will be insulated from the interior and penetrated with carefully placed windows which act to frame the historic architecture. Sliding glass walls in the west portion of the barn will allow for the space to be fully opened up to the outdoor environment when natural conditions are favourable. 


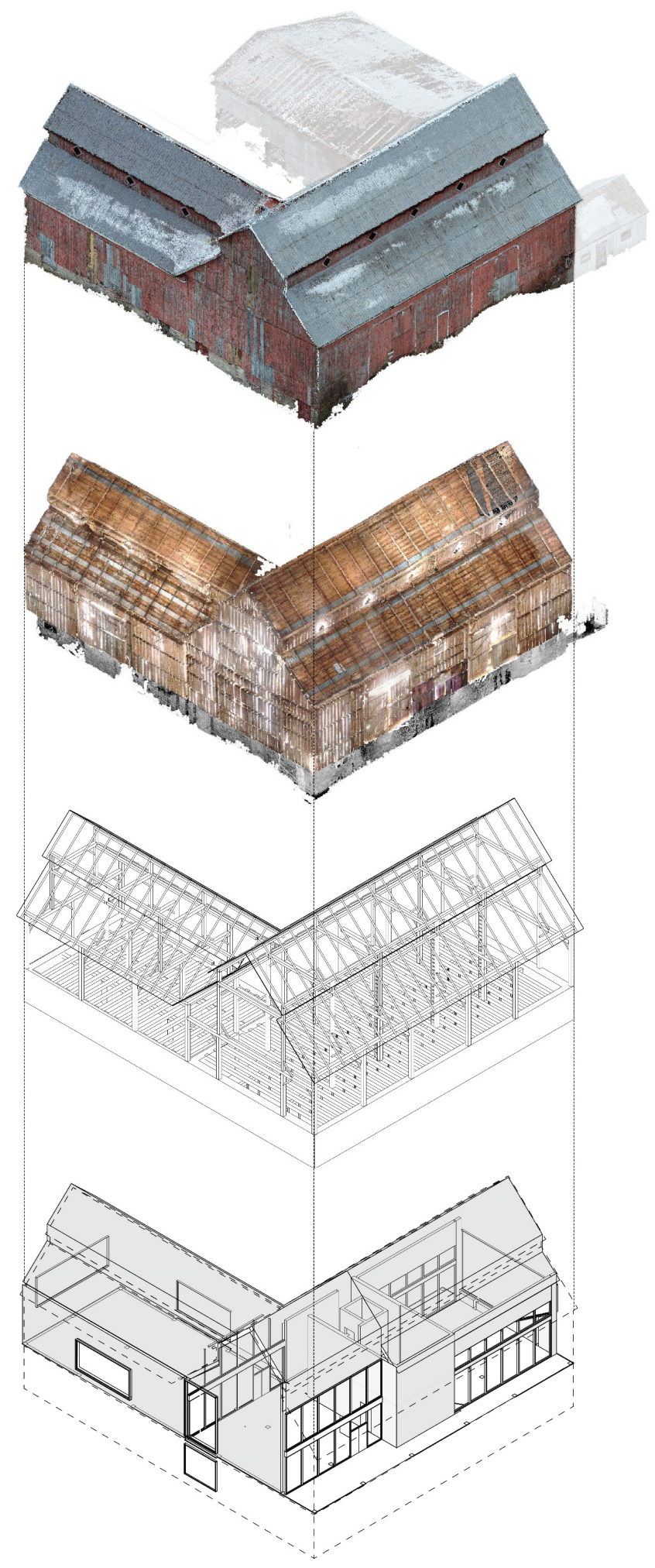

Illustration 20 Stacked axonometric diagram including massing of intervention. 


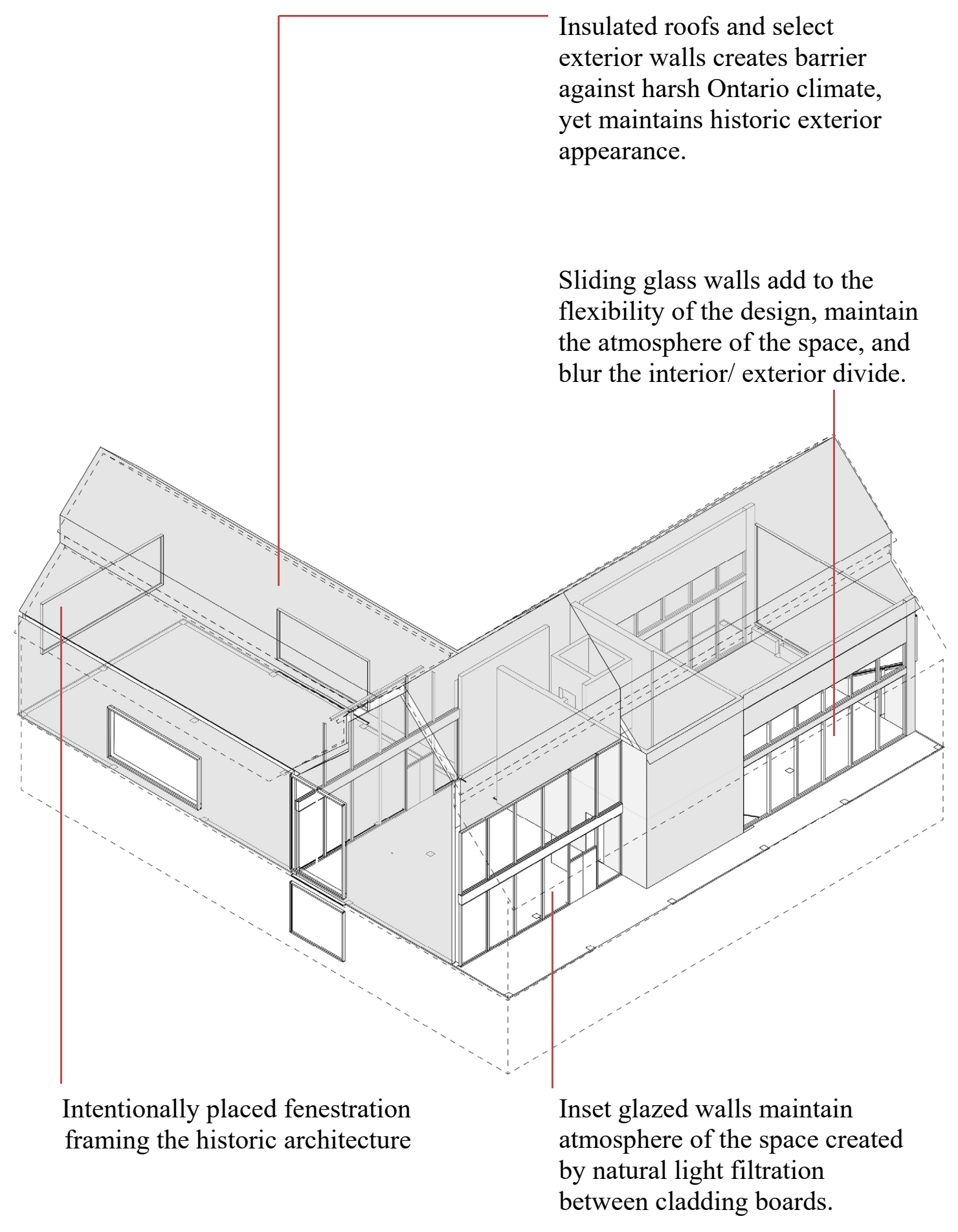

Illustration 21 Massing diagram of schematic design intervention. 


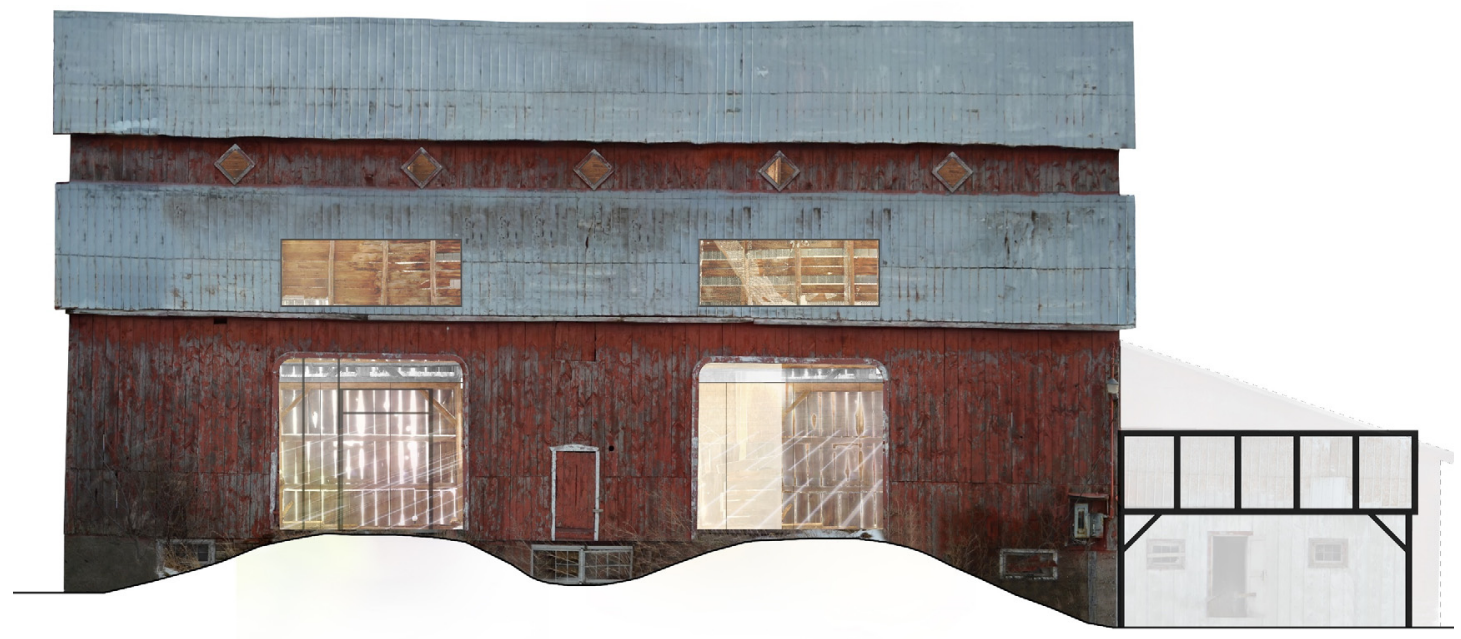

Illustration 22 North elevation, showing new schematic design.

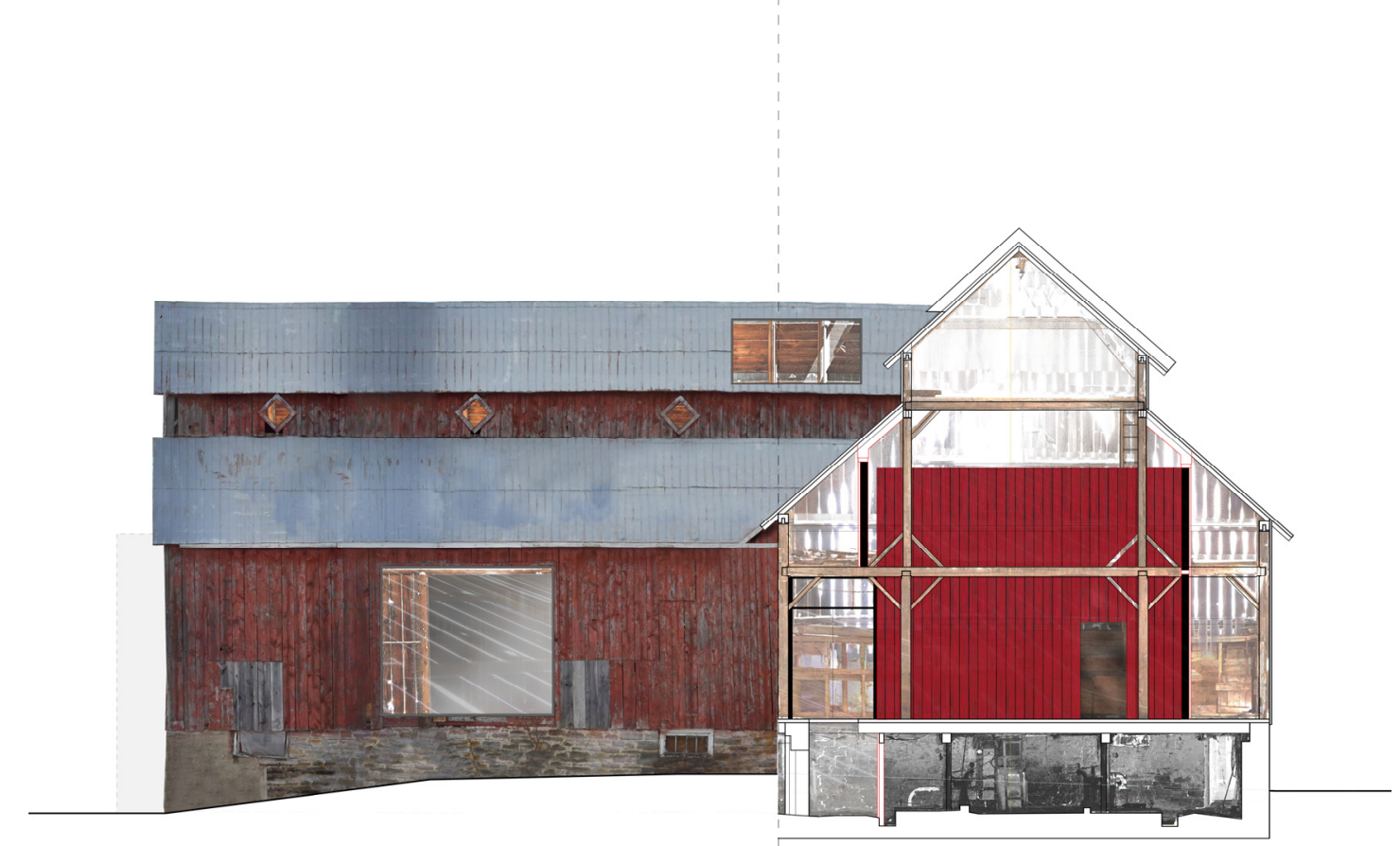

Illustration 23 East elevation, showing new schematic design. 


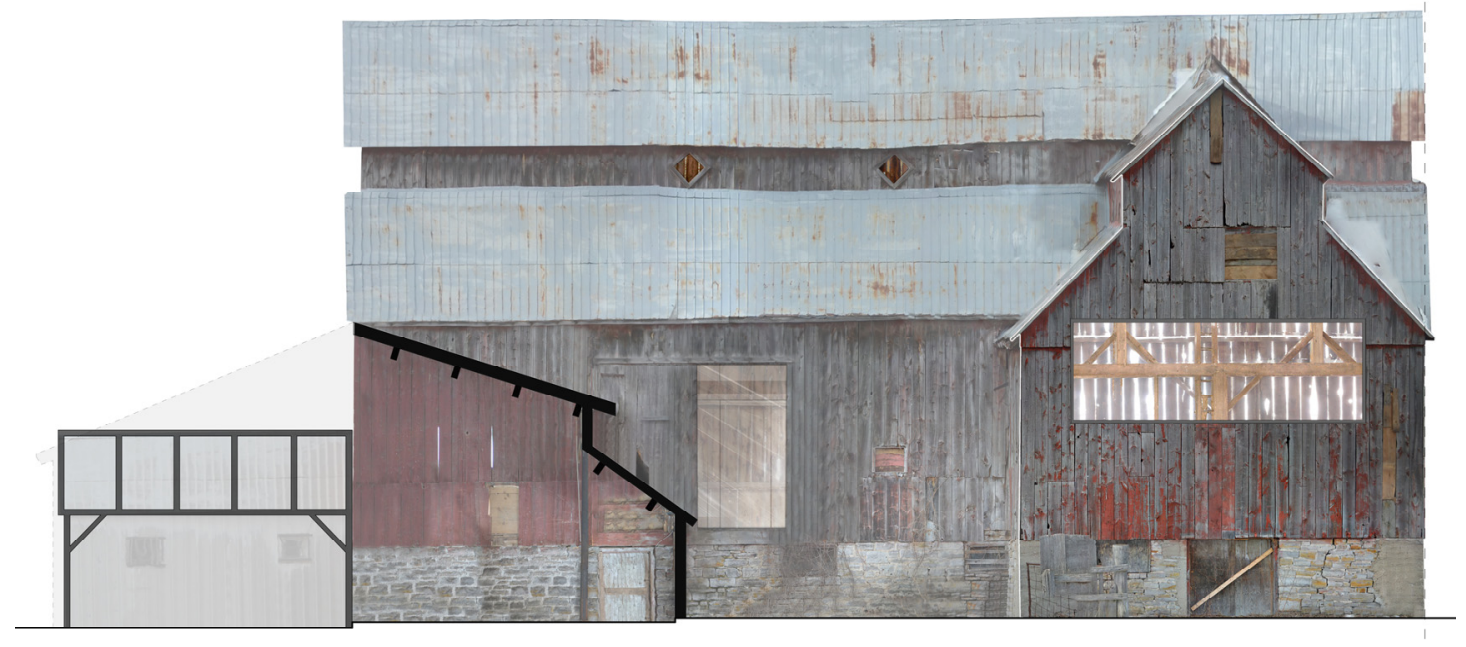

Illustration 24 South elevation, showing new schematic design.

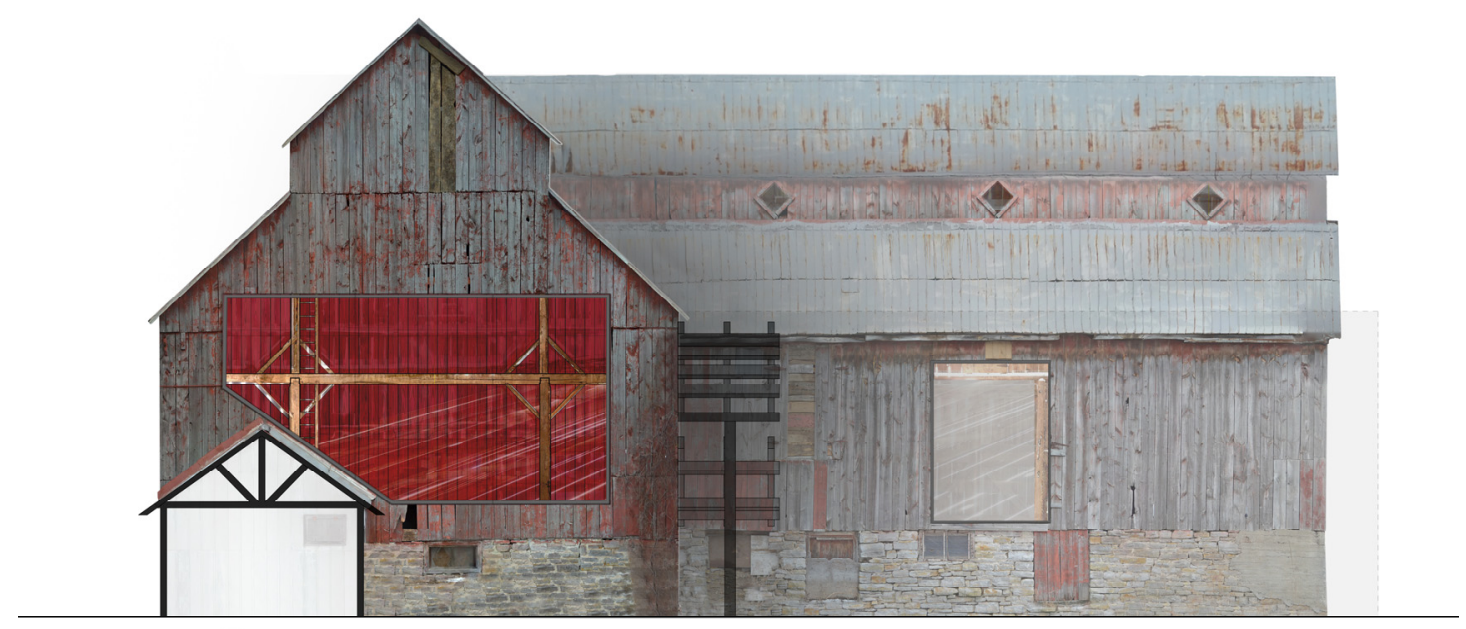

Illustration 25 West elevation, showing new schematic design. 

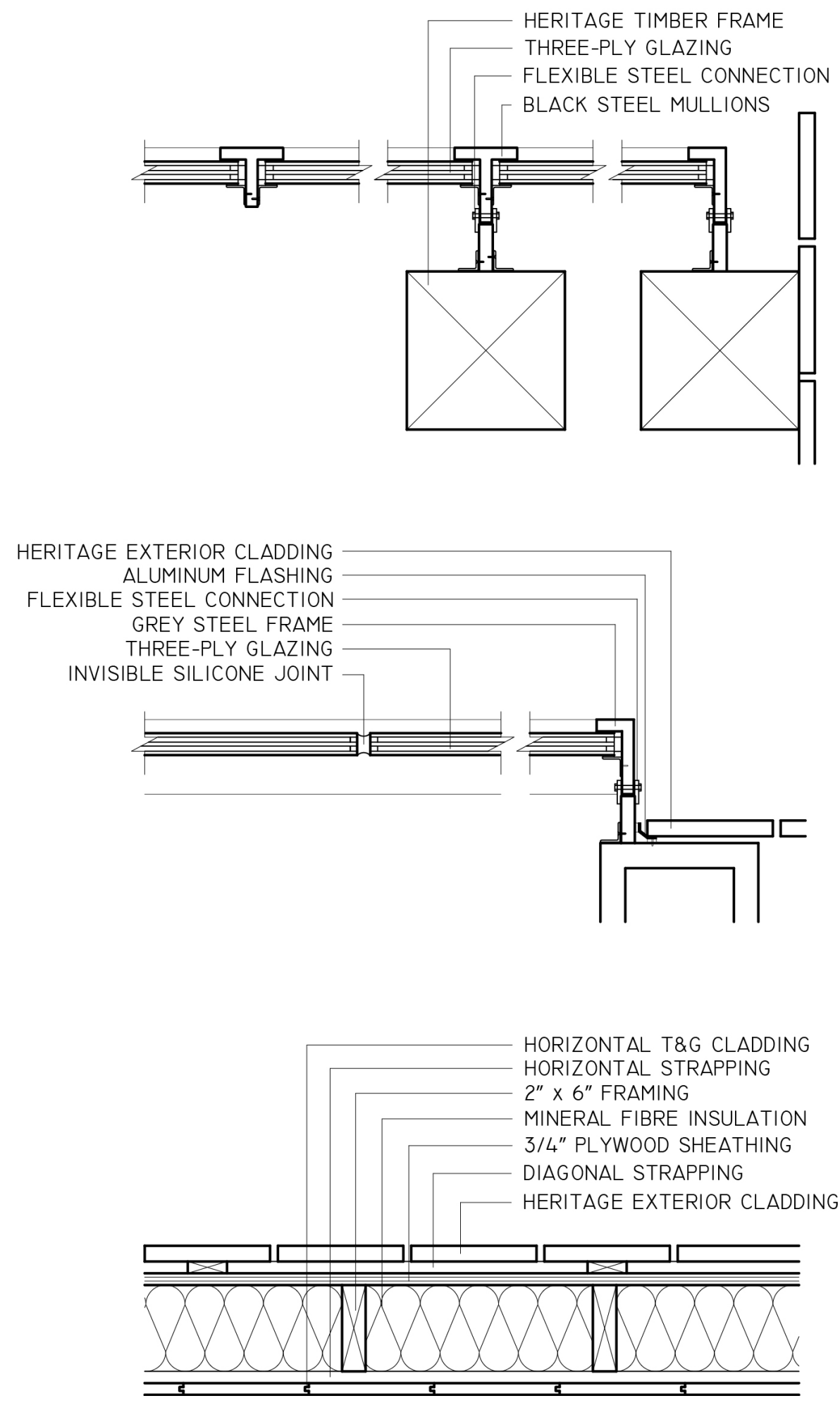

Illustration 26 Inset Glazing, Seamless Glazing, and Insulated Wall Details. 


\section{Summary}

McIlwraith proposes an interesting take on rural versus urban, suggesting that the rural landscape is our story, a truly vernacular development, whereas the city represents someone else's story subject to outside influence. This concept is intriguing, for if the rural represents our story, there exists the potential within adaptation of barns to bring our story back into the suburban landscape. Remnants of a once rural environment, full of depth and cultural history, barns hold the promise of bringing rootedness and a sense of identity to majorly anonymous suburban communities. This design is but one of the many ways a respectful adaptation may be physically and programmatically integrated into the Bradley-Craig Barn. 


\section{Bibliography or References}

Allston, Dave. "You'll never know what you'll find at Crazy Carl's." Kitchissippi Times, December 10, 2015. https://kitchissippi.com/2015/12/10/crazy-carls-antiques/

Arthur, Eric and Dudley Witney. The Barn: A Vanishing Landmark in North America. Toronto: M. F. Feheley Arts, 1972.

Bahl, Vani. "Ethics of Adaptive Reuse." Architecture Week (2005) accessed January 08, 2018, http://www.architectureweek.com/2005/0518/building_1-2.html.

Brandt, Mark Thompson. "Re: Bradley-Craig Barn and Proposed Property Development, 590 Hazeldean Road, Stittsville." MTBA review of application for demolition and relocation, January 22, 2016.

Commonwealth Resource Management. “A Cultural Heritage Impact Statement: Bradley/Craig Barn Demolition \& Relocation 590 Hazeldean Road, Ottawa.” September 2015.

Cooke, John G. \& Associates Ltd. "Historic Barn Condition Survey: Craig Family Farm, 590 Hazeldean Road, Kanata.” January 6, 2010.

Egan, Kelly. "After 140 years, it took heritage nod to make barn shaky." Ottawa Citizen, May 19, 2014. http://ottawacitizen.com/news/local-news/after-140-years-it-tookheritage-nod-to-make-barn-shaky

Endersby, Elric, et al. Barn: Preservation \& Adaptation. New York: Rizzoli, 2014.

Evans, Marguerite. "The Vulnerable Bradley/ Craig Hazeldean Property” The Historical Society of Ottawa News, no. 143 (January 2014): 7-10.

McIlwraith, Thomas F. Looking for Old Ontario. Toronto: University of Toronto Press Ltd, 1997.

Jessen, Johann and Jochem Schneider. "Conversions - the new normal." In Building in Existing Fabric: Refurbishment, Extensions, New Design, edited by Christian Schittich, 11-21. Berlin, Basel, Boston: Edition Detail, Birkhäuser, 2003.

Sloane, Eric. A Reverence for Wood. Important Books, 2013.

City of Ottawa. "Fernbank Community Design Plan." Accessed April 1,2018. https://ottawa.ca/en/city-hall/planning-and-development/community-plans-anddesign-guidelines/community-plans-and-studies/community-designplans/fernbank-community-design-plan 
City of Ottawa. "Official Plan.” May 2003. https://ottawa.ca/en/city-hall/planning-anddevelopment/official-plan-and-master-plans/official-plan

City of Ottawa. "Ontario Heritage Act.” Last modified February 28, 2017. http://www.mtc.gov.on.ca/en/heritage/heritage_act.shtml

Council of Europe Portal. "Faro Convention Action Plan." Culture and Cultural Heritage. Accessed February 28, 2018. https://www.coe.int/en/web/culture-andheritage/faro-action-plan.

Fagan, Laurie. “"That's not progress': Stittsville farm's last inhabitant blasts developer's inaction." $C B C$ New, January 30, 2018. http://www.cbc.ca/news/canada/ottawa/ heritage-stittsville-farm-barn-richcraft-1.4508684

Ontario.ca "2014 Provincial Policy Statement.” Planning Act. April 30, 2014. http://www.mah.gov.on.ca/AssetFactory.aspx?did=10463

UNESCO, "Intangible Cultural Heritage." Accessed January 06, 2018. https://ich.unesco.org/en/what-is-intangible-heritage-00003.

Wilson, Catherine Anne. "Reciprocal Work Bees and the Meaning of Neighbourhood." Canadian Historical Review 82, no. 3 (September 2001): 431-464. 